\title{
Regional Heterogeneity of the Family Farming in Brazil: an Analysis Using a Spatial Stochastic Frontier
}

\author{
Thyena Karen Magalhães Dias \\ Ph.D Student in Rural Economics at the Federal University of Ceará \\ E-mail: thyena.karen@hotmail.com \\ https://orcid.org/0000-0002-9200-8901
}

\begin{abstract}
Edward Martins Costa
Associate Professor at the Department of Agricultural Economics at the Federal University of Ceará

E-mail: edwardcosta@ufc.br

https://orcid.org/0000-0002-9187-8534
\end{abstract}

Filipe Augusto Xavier Lima

Associate Professor at the Department of Agricultural Economics at the Federal University of Ceará

E-mail: filipeaxlima@yahoo.com.br

https://orcid.org/0000-0003-4235-1311

Helson Gomes de Souza (Corresponding author)

Ph.D Student in Applied Economics at the Federal University of Paraíba.

E-mail: helson.souza@academico.ufpb.br

https://orcid.org/0000-0001-7873-3798

Received: May 29, 2021 Accepted: June 29, $2021 \quad$ Published: July 17, 2021

doi:10.5296/jas.v9i3.18688

URL: https://doi.org/10.5296/jas.v9i3.18688 


\section{Abstract}

Family farming is quite different between Brazilian regions, where one of the main factors of this distinction is the implementation of agricultural modernization that initially benefited the regions South and Southeast, making these regions more mechanized and with a higher level of human capital. Given this fact, this article aims to measure the productive differences of family farmers between Brazilian regions using data from the 2017 Agricultural Census and applying a spatial stochastic frontier at municipal level. The results have shown that there is a high heterogeneity between Brazilian regions, where although all areas have shown a decreasing return of production scale, these returns were greater for the regions Midwest, Southeast, and South. Besides, technology and labor have a lesser effect on the gross income of farmers in the Northeast. The results also show that spillovers were different between regions, both for the factors of production and for the determinants of inefficiency. Furthermore, the heterogeneity can be confirmed by the efficiency scores, which were higher in the regions South, Midwest, and Mid-South regions of the Southeast. The results also suggest that, according to the profile of each region, it is necessary to implement more efficient policies that aim to improve the effectiveness of existing policies and mitigate the differences between them, especially in the North and Northeast of Brazil.

Keywords: family agriculture, agricultural modernization, spatial stochastic frontier, technical efficiency

JEL classification: Q12; Q15; Q18.

Funding: Not applicable.

- Conflicts of interest/Competing interests: There are not conflicts of interest in this work.

- Availability of data and material: All data used in this work can be obtained through a request to the authors.

- Code availability: All statistical procedures in this work was made in R. The codes can be obtained through a request to the authors.

\section{Introduction}

Brazil is one of the main producers and suppliers of agricultural products worldwide, and this fact relates, among other factors, to the agricultural mechanization process that occurred in the country in the 1960s. As a result of this modernization, there were some transformations in the population and in the land structure of this productive sector due to the migration process, changing international agricultural markets, and traditional local cultures. During this period, there were several technological and organizational changes aimed at increasing agricultural productivity, such as the use of pesticides, fertilizers, machinery and equipment, irrigation techniques, and improved seeds (Almeida, 2011).

For that, the participation of the government was decisive in making this process viable, mainly through policies that facilitated this implementation, given the national interest in 
increasing the Brazilian agricultural exports, also aiming at an increase of the country's trade balance. Examples of these actions are credit viability, the creation of research institutes, the strengthening of technical assistance, and others (Neto et al. 2010).

Despite the growth of agriculture, mainly driven by the agribusiness, given the technological increase achieved by the sector and its goal of increasing the level of production in the country, mechanization did not occur uniformly among the different regions of Brazil, not only maintaining, but also increasing the heterogeneity of the Brazilian agriculture. Thus, public policies applied in rural areas had different impacts, affecting the categories of producers and the regions in distinct ways, since the focus of these policies was concentrated essentially in the South and Southeast regions and predominantly under the attribution of medium and large producers (Neto et al. 2010, Sorj 2008).

As a result, the majority of small producers were dependent on traditional agricultural techniques, especially in regions where there was no modernization, or the modernization was incipient. According to Abramovay (1997) this group of producers is known as Brazilian Family Farming, which is composed not only by subsistence producers but also by small capitalized producers. Besides, the technologies for allocating the factors of production in Brazilian Family Farming establishments are also different, since some establishments are more capitalized, hence their production process uses modern techniques being more capital-intensive, while other producers are more labor-intensive (Guanziroli \& Di Sabbato 2014, Guanziroli et al. 2012, Vieira Filho 2014). According to Hoffmann (1992), Vieira Filho (2014), Neto, de Melo \& Maia (2010), Sorj (2008), this characteristic is a result of the asymmetric mechanization process that occurred place in the Brazilian rural areas.

Based on this contextualization, we seek to answer the following questions: what is the difference in technical efficiency between Family Farming establishments, given the uneven modernization process between the Brazilian regions? Is it possible to affirm that family farming establishments in the more mechanized regions are more efficient in allocating production factors? And what is the impact of these factors of production on the gross value of production in each region, considering the effects of spatial spillover in neighboring regions? To meet the objective of measuring the productive differences of Brazilian Family Farming establishments at the regional level, we used data from the 2017 Brazilian Agricultural Census and organized the information at the municipal level. This data set contains the most recent information on agriculture in Brazil. Subsequently, we use this data to estimate a stochastic frontier of production using a spatial functional form.

Finally, it is necessary to highlight the productive performance of this category of farmers and their differentiation between Brazilian regions, given their economic importance for the agricultural Gross Domestic Product. Also, it is important to consider factors such as the technological, climatic and geographical peculiarities of Brazilian family farming. In addition, this study contributes to the literature given the scarcity of works that differentiate production efficiency and its measurement between Brazilian regions. Also, this study is the first to specify only family farming establishments and use the most recent data on agriculture in country. Finally, this work is a pioneer in the application of a stochastic production function 
with spatial techniques, being innovative when using this method particularly for family farmers in Brazil and its regions.

The work is structured in five sections, in addition to this introduction. In the second section we make a brief review of the literature on family farming, showing the works already existing in the stochastic frontier literature of Brazilian agriculture. After, we present information about the data and methodology used. In the fourth section, we show the results related to the objective of the study, and finally, we detail the main results of the work in the concluding remarks.

\section{Literature Review}

\subsection{The Modernization Process of Brazilian Agriculture and the Family Farming}

Since the 1960s, the modernization of Brazilian agriculture has generated technological changes in rural areas due to the greater use of industrial inputs, machines, and equipment. Seeking to increase productivity, this process took place through public policies aimed at rural producers, such as rural credit, minimum prices, rural insurance, and others (Delgado 2005). In addition to these policies, the government also created and expanded technical assistance and rural extension, research and storage services, through the Brazilian Technical Assistance and Rural Extension Company (Empresa Brasileira de Assistência Técnica e Extensão Rural - Embrater) and the Brazilian Agricultural Research Corporation (Empresa Brasileira de Pesquisa Agropecuária - Embrapa) (Sorj 2008).

However, with the main objective of increasing agricultural exports, the implementation of modern techniques did not occur symmetrically. The less dynamic sectors of the agro-industrial system, as well as non-exportable products, did not have the same benefits as the others. The main beneficiaries of this process were the large agricultural producers located in the South, Southeast, and Midwest regions of the country, and exportable products, which generated an increase in regional productive inequalities (Leite 2001, Matos \& Pessoa 2011).

The modernization process can be measured by the increase in physical capital and the increase in the use of pesticides. Thus, based on data from the Brazilian Institute of Geography and Statistics Foundation (Fundação Instituto Brasileiro de Geografia $e$ Estatística - FIBGE) and census information from 1950 to 1985, Teixeira (2005) verified an increase in the number of tractors throughout the studied period (while in 1950 there were 8,372 , in 1985 the number of tractors was 665,280), showing signs of changes caused by the mechanization model implemented in the country. Beyond this production factor, Graziano (1985) also verified a significant increase in the use of artificial fertilizers and pesticides with an average use rate increase of $60 \%$ and 25\%, respectively, from 1965 to 1975.

Table 1 shows the composition of physical capital (tractors, implements and machines) existing in Brazilian agricultural establishments by region according to (IBGE, 2017). It is possible to verify the continuity of the concentration of these items in the South and Southeast regions, which have approximately $74.3 \%$ of the total of tractors, machines, and agricultural implements. This domain can also be observed from the number of tractors 
(representing, on average, $61 \%$ of the physical capital used) since the information in the table points to a current concentration of $72 \%$ of that capital in the mentioned regions, corroborating with Graziano (1985). Besides, family farming, which corresponds to $76.82 \%$ of rural establishments in the country, has $43.46 \%$ of the total physical capital. This result shows that despite making up the majority of rural establishments, family farming has a lower percentage of capital.

Table 1. Number of tractors, implements and machines in agricultural establishments by region of Brazil

\begin{tabular}{ccccccc}
\hline \multirow{2}{*}{ Region } & \multicolumn{2}{c}{ Total } & Family Farming (Yes) & $\begin{array}{c}\text { Family Farming } \\
\text { (Not) }\end{array}$ \\
\cline { 2 - 7 } & Total & Tractors & Total & Tractors & Total & Tractors \\
\hline Brazil & $2,013,105$ & $1,229,907$ & $1,138,220$ & 680,335 & 874,885 & 549,674 \\
North & 80,957 & 58,436 & 61,004 & 42,170 & 19,953 & 16,266 \\
Northeast & 119,201 & 83,866 & 83,458 & 57,224 & 35,743 & 26,642 \\
Southeast & 566,247 & 373,952 & 360,040 & 230,014 & 206,207 & 143,938 \\
South & 929,245 & 517,042 & 371,776 & 192,633 & 557,679 & 324,409 \\
Midwest & 317,245 & 196,611 & 261,942 & 158,294 & 55,303 & 38,317 \\
\hline
\end{tabular}

Source: Elaborated by the authors according to 2017 Brazilian agricultural census.

Among the public policies implemented, the most important one was rural credit, which allowed the ability to obtain modern technologies, inputs, and others, allowing to increase productivity (Costa \& Filho 2018). However, given the restrictions related to bureaucracy, lack of information, and guarantees required by the banking system, this policy created inequalities, given that small producers had greater difficulties in accessing it (de Almeida et al. 2010).

Thus, one of the main obstacles to the production of family farming establishments is the low level of financial capitalization, which restricts access to inputs, equipment, and machinery, which may cause less productivity to the farmer. These tools allow the production to be feasible in the face of natural problems through soil fertilization, genetically modified seeds, mechanization, irrigation, and others (Mariano \& Pinheiro 2009, Teixeira 2005).

Thus, in 1996 the Brazilian government created the National Program for Strengthening Family Agriculture (Programa Nacional de Fortalecimento da Agricultura Familiar PRONAF), main rural credit policy specifically dedicated to family farmers, allowing the 
inclusion of this group in the dynamism of Brazilian agriculture. To be a PRONAF beneficiary, the farmer needs to obtain the Declaration of Aptitude to PRPNAF (Declaração de Aptidão ao Pronaf - DAP), which indicates which establishments are considered family farming establishments according to Law No. 11,326 (Family Agriculture Law) (BRAZIL, 2006).

Since its implementation until the current years, Pronaf has undergone both institutional and financial advances and evolutions, as noted by Schneider et al (2021), who highlighted that this trajectory resulted in a greater volume of financial resources, and a greater distribution of these both among Brazilian regions and among the different income levels of family producers, however, there is still a need for some corrections in the program.

However, despite the importance of family farming, mainly in the occupation of rural labor and in supplying the agri-food sector, the government does not privilege this group of producers. This fact can be seen from the $35 \%$ cut in PRONAF resources, and approximately $26 \%$ in the budget proposal for 2021 for economic subsidies in agriculture, such as rural credit, rural insurance, and marketing support, even in the face of increased costs of production of these farmers (CANAL RURAL, April 14, 2021).

In summary, Brazilian family farming establishments have distinct characteristics. where according to Guanziroli (2001): (i) In the Northern region, family farmers face restrictions imposed both by the environment and by the unsustainability of agricultural practices used in the region, increasing the demand for new land; (ii) The Northeast region is characterized by the concentration of family farming establishments that have low-income levels. The region also has a high scarcity of natural, water, and land resources, in addition to having a large number of agricultural and production systems, due to the diversity of family farmers in the region; (iii) The Southeast region has high levels of capitalization and dynamism, where despite the great disparity between family farming establishments, it is possible to indicate that the dynamics in this region are related to non-family farming, making small farmers dependent on the decision making of large agricultural establishments; (iv) In the South region, family farming is an autonomous segment, where production has great economic and political influence; and (v) Despite having a lower concentration of family farming establishments, the Midwest region has great importance in the growth of the regional economy.

\subsection{Technical Efficiency of the Rural Establishments}

According to Aquino, Gazolla \& Schneider (2018), due to the different climatic, geographical, technological, and institutional conditions that affect in some way, the technical efficiency of family farming in each region of Brazil, these regions generally have different levels of performance. These authors emphasize that the development of research that seeks to measure the effects of the allocation of endogenous and exogenous factors of production on the gross value of family farming production in Brazil at the regional level is extremely important.

According to Coelli, Rao, O’Donnell \& Battese (2005), technical efficiency shows the 
optimal combination of production inputs that generate the maximum product. Few studies in the literature consider the type of farmer (family and non-family farmer). Existing studies on family farmers and small producers generally aim to analyze technical efficiency for a specific location, culture, or seeks to make a comparison between non-family rural establishments (Imori et al. 2012, Almeida 2012, Bravo-Ureta \& Evenson 1994, Bravo-Ureta\& Pinheiro 1997, Binam et al. 2005, Seyoum et al. 1998, Ajibefun et al. 2006, Nehring et al.2009).

Among the works in the literature that use the spatial stochastic frontier method in other sectors, we can to cite: (i) Adetutu et al (2015): these authors analyze the effects of efficiency and the growth of Total Factor Productivity (TFP) on pollution in Europe; (ii) Tsionas \& Michaelides (2016): in this work the authors analyze the technical efficiency for the Italian regions; (iii) Tsukamoto (2019): makes an application to the Japanese manufacturing industry; and (iv) Vidoli, et al (2016): these authors estimate the efficiency for the Italian wine industry.

Regarding the few studies applied to the agricultural sector, Pede et al (2018) aimed to analyze the spatial dependence in the technical efficiency estimates of rice producers in Central Visayan Island of Bohol, Philippines, from 2009 to 2011. The authors estimated spatial and non-spatial models and observed that there is a spatial dependence at residential levels and found that this spatial dependence is greater for irrigated farms when compared to non-irrigated farms. The authors also concluded that as the spatial dependence increases, the average efficiency also increases.

Specifically in Brazil, Scherer \& Porsse (2017) aimed to analyze the productive efficiency of agriculture at the micro- regional level separately for permanent and temporary crops using the 2006 Census. The authors concluded that there are high-efficiency clusters for the permanent crops in the regions Northeast and South. Regarding temporary crops, the authors observed the existence of few high-efficiency clusters at Northeast and Southeast regions. Schmidt et al (2009) analyzed the productivity of agricultural establishments in 370 municipalities in the Brazilian Midwest using Census data from 1995/96. When testing some stochastic boundary models, the authors found that a model with spatial effects was more suitable for this type of analysis.

\section{Methodology}

\subsection{Data and Variables}

This research uses cross-sectional data for the year 2017. We choose this specific period because in this year the Brazilian Institute of Geography and Statistics (Instituto Brasileiro de Geografia e Estatística- IBGE) performed the Brazilian Agricultural Census ${ }^{1}$. Therefore, this work uses the data for the year 2017 because it is the most actual year that has census information on the activities of the Brazilian rural sector.

\footnotetext{
1 The Brazilian Agricultural Census is national research that seeks to collect information on the rural producers and the activities of the rural sector in Brazil. Generally, the rural census occurs every ten years. The two versions of the Brazilian rural census previously to the year 2017 occurred in 1996 and 2006.
} 
Our sample is composed by 4,362 Brazilian municipalities distributed among the 26 Brazilian states and the Federal District ${ }^{2}$. The statistical procedures that we realize in this work are made considering the total sample and five sub-samples referring to the five Brazilian regions ${ }^{3}$.

Most of the variables that we used were extracted from the Brazilian rural census, made available by IBGE (2017). However, we also use additional covariates made available by other sources. The details on the variables used in this work and their respective sources are shown in Frame 1.

Frame 1. Description and source of the variables

\begin{tabular}{|c|c|c|c|}
\hline $\begin{array}{c}\text { Variable } \\
\text { name }\end{array}$ & Description & $\begin{array}{c}\text { Unit of } \\
\text { measurement }\end{array}$ & Source \\
\hline $\mathrm{Y}$ & $\begin{array}{l}\text { Gross value of family farming } \\
\text { production. }\end{array}$ & $\mathrm{R} \$ 1,000.00$ & IBGE (2017) \\
\hline Labor & $\begin{array}{c}\text { Number of persons employed } \\
\text { in family farms. }\end{array}$ & Units & IBGE (2017) \\
\hline Technology & $\begin{array}{c}\text { Number of tractors, machinery } \\
\text { and agricultural equipment on } \\
\text { family farms. }\end{array}$ & Units & IBGE (2017) \\
\hline $\begin{array}{c}\text { Expenses } \\
\text { with inputs }\end{array}$ & $\begin{array}{l}\text { Total value of expenditure on } \\
\text { input from family farms. }\end{array}$ & $\mathrm{R} \$ 1,000.00$ & IBGE (2017) \\
\hline Area & $\begin{array}{l}\text { Total planted area in family } \\
\text { farms. }\end{array}$ & Hectares & IBGE (2017) \\
\hline Irrigation & $\begin{array}{l}\text { Number of family farms using } \\
\text { irrigation per municipality. }\end{array}$ & Units & IBGE (2017) \\
\hline $\begin{array}{l}\text { Technical } \\
\text { assistance }\end{array}$ & $\begin{array}{l}\text { Number of family farms that } \\
\text { received technical assistance } \\
\text { by municipality. }\end{array}$ & Units & IBGE (2017) \\
\hline Rural credit & $\begin{array}{l}\text { Total value of rural credit } \\
\text { contracts for the costing, } \\
\text { investment and } \\
\text { commercialization of family } \\
\text { farms per municipality. }\end{array}$ & $\mathrm{R} \$ 1,000.00$ & IBGE (2017) \\
\hline Precipitation & Annual average precipitation. & $\begin{array}{l}\text { Millimeters } \\
(\mathrm{mm})\end{array}$ & $\begin{array}{l}\text { Camarillo-Narjano } \\
\text { et al (2019) }\end{array}$ \\
\hline Temperature & Annual average Temperature & ${ }^{\circ} \mathrm{C}$ & $\begin{array}{l}\text { Camarillo-Narjano } \\
\text { et al (2019) }\end{array}$ \\
\hline
\end{tabular}

Source: Elaborated by the authors.

\subsection{Stochastic Production Frontier}

To meet the objectives proposed in the introductory section, we use the method known as Stochastic Production Frontier (SPF). It is a technique widely disseminated in the literature. This method allows modeling a production possibility frontier using an econometric model

\footnotetext{
2 In total, Brazil has 5,570 municipalities, according to IBGE (2020). However, the sample disregards 1,208 municipalities due to missing data, outliers, or statistical incompatibility of the information.

${ }^{3}$ Brazil has five major regions - North (Norte), Northeast (Nordeste), South (Sul), Southeast (Sudeste) and Midwest (Centro-Oeste) - and we perform the estimates for the total sample and for each of these regions. For more details of the Brazilian territorial division,

see https://www.ibge.gov.br/geociencias/organizacao-do-territorio/divisao-regional/15778-divisoes-regionais-do-brasil.html? =\&t $=$ o-que-e.
} 
where the production of a specific agent is calculated as a function of the inputs available to the creation of the product in addition to an estimation error component. Aigner, Lovell \& Schmidt (1977) proposed to estimate an SPF with the following specification.

$$
\ln \left(y_{i}\right)=\beta x_{i}+v_{i}+u_{i}
$$

Where $y_{i}$ represents the gross production value for the firm $i, x_{i}$ is the matrix with the production factors for each firm $i$, and $v_{i}$ is a vector containing the random estimation errors related to the effects of the variables that can not be observed in the estimation but has a relation with $y_{i}$. Just as indicated by Aigner, Lovell \& Schmidt (1977), we assume that the values of $v_{i}$ are independent and identically distributed, having a normal distribution with mean zero and constant variance, $\sigma_{i}^{2} \cdot u_{i}$ also is independent and identically distributed, with a truncated normal distribution between zero and the unity. Besides, $u_{i}$ does not depend on the values of $u_{i}$.

Following the specification of Battese \& Coelli (1995), $u_{i}$ is a non-negative random variable associated with the technical inefficiency of the production. This term has mean $z_{i \delta}$ and variance $\sigma_{i}^{2}$, so that $z$ is a column vector $(1 \mathrm{x} \mathrm{m})$ containing the variables related to the technical inefficiency of the production for each firm, and $\delta$ is a vector ( $\mathrm{mx} 1$ ) that contains the unknown coefficients that will be estimated. Besides, the mentioned authors also indicate that the effects of the technical inefficiency obtained by the estimation of the Equation 1 can be written as:

$$
u_{i}=\delta z_{i}+\omega_{i}
$$

Where $\omega_{i}$ is a random variable defined by truncation of the normal distribution with mean zero and variance $\sigma_{i}^{2}$ when the truncation point is $\delta z_{i}$ which implies $\omega_{i}>-\delta z_{i}$. From these concepts, Battese $\&$ Coelli (1995) define the technical efficiency of the i-th firm as:

$$
T E=-\exp \left(-\delta z_{i}-\omega_{i}\right)
$$

In this study, we consider that the municipalities are the firms in the model, with $y$ representing the gross production value from the municipal family farming, $\mathrm{x}$ is the matrix composed of the variables capital, labor, technology, and land. Besides, we assume that the technical inefficiency is explicated by the variables that indicate the irrigation, technical assistance, rural credit, precipitation, and temperature.

\subsection{The Spatial Specification to SPF}

To verify if there are indirect spatial effects in the production frontier, and consequently, if there is a spatial spillover in the components of the SPF, we use the method indicated by Adetutu et al (2015). In this case, the authors proposed an SPF with the functional form of a Spatial Lag X model (SLX model). For this, it's necessary to make some assumptions and to consider some additional statistical procedures. 
Initially, we assume that, if there is a spillover effect in the SPF, so this effect has only a local reach, that is, changes in the production mechanisms of family farming in a given municipality cause change only in the production mechanisms of the municipality itself and in the surrounding municipalities. This assumption justifies the use of a local model to the detriment of a global model $^{4}$. Another assumption that we made indicates that if the SLX model is not suitable for estimating an SPF, so this specification can be estimated by Ordinary Least Squares (OLS) ${ }^{5}$.

A basic rule in empirical econometric applications indicates that if there is autocorrelation between the residuals of the observations, so the average square error of the OLS estimator may not be the minimum average square error, causing an inefficient estimation. However, when the data are distributed in space, there is the possibility of quantifying and correcting the inefficiency generated by the spatial autocorrelation of the residuals.

Assuming that the SPF can be estimated by OLS according to Equation 1, we estimate the residual value, $\mu_{i}=v_{i}+u_{i}$. To verify if these residuals are spatially autocorrelated we use the Global Moran Index according to the following equation:

$$
I=\frac{n}{\sum \sum W_{i j}} \frac{\tau^{\prime} W \tau}{\tau^{\prime} \tau}
$$

Where $n$ is the number of municipalities, $\tau$ represents the padronized values of $\mu_{i}$, and $W$ is a spatial weights matrix $(\mathrm{n} \times \mathrm{n})^{6}$. The null hypothesis of the test indicates that $\mu_{i}$ is randomly distributed. I varies between -1 and 1 , so that, if $I<0$, so the values of $\mu_{i}$ has negative spatial autocorrelation; if $I>0$, so the values of $\mu_{i}$ has positive spatial autocorrelation; and if $I=0$, so the values of $\mu_{i}$ are randomly distributed in the space.

If the residuals are not randomly distributed, the next step is to estimate the SLX model and to verify the application of this method in the research problem. Following the steps indicated by Vega \& Elhorst (2015), initially we estimate the next equation:

$$
\ln \left(y_{i}\right)=\alpha+\beta x_{i}+\theta W x_{i}+u_{i}
$$

Where $\beta$ is the direct effect of $x$ on $y, \theta$ is the spillover effect of $x$ on $y$ and $z_{i}$ now has mean $z_{i} \delta+\eta W z_{i}$, where $\eta$ is a vector of unknown parameters that represents the indirect spatial effects of the variables that determine the inefficiency. After estimating the SPF with the functional form presented in the Equation 5, we test the null hyphotesis $\theta=0$ e $\eta=0$. If it is not possible to reject either null hypothesis, then the estimation of Equation 1 is preferable to the estimation of Equation 5. If $\theta \neq 0$ e $\eta \neq 0$ or $\eta=0$, then the SPF with

\footnotetext{
${ }^{4}$ For more details on the functional form of the spatial econometric models, see Vega \& Elhorst (2015).

5 We use this assumption only to test if the SLX model is adequate to estimate the SPF. After performing the model selection tests, the estimates will be made by maximum likelihood.

${ }^{6}$ In this work we use a matrix of $\mathrm{k}$ nearest neighbors. To construct this matrix, we consider the Euclidean distance between the municipalities and calculate the spatial weights matrix according to the inverse distance of those k neighbors in relation to each of the municipalities.
} 
the specification of an SLX model is preferable to the estimation of Equation 1. After choosing the best functional form, we estimate FEP by maximum likelihood, as indicated by Coelli, Rao, O’Donnell \& Battese (2005).

If the SLX specification is more adequate to estimate the SPF, so the technical efficiency is calculated as ${ }^{7}$ :

$$
T E_{i}=-\exp \left(-\delta z_{i}-\eta W z_{i}-\omega_{i}\right)
$$

\section{Results}

\subsection{Descriptive Statistics}

Table 3 shows the descriptive statistics of the variables for the complete sample of Brazilian municipalities. Supposing that the arithmetic average represents the true average for each variable, it's possible to see that the average production of family farming in Brazilian municipalities is approximately $\mathrm{R} \$ 16$ million, it is, on average, in 2017, each Brazilian municipality produced around $\mathrm{R} \$ 16$ million with products from family farming. It is possible to see also that the Brazilian family farm has, on average, approximately 1,900 workers in each municipality.

In general, in 2017, Brazilian municipalities had, on average, approximately 198 machines or agricultural equipment in family farming establishments; approximately R \$ 7,213 invested in family farming activities; approximately 16,142 hectares were destined to family farming activities; and approximately 78 family farming establishments that used irrigation techniques. Besides, the average value of rural credit destined for family farming in Brazilian municipalities in 2017 was around $\mathrm{R} \$ 4.8$ million. Descriptive statistics also show that the sample municipalities in 2017 had an average annual rainfall of $1.382 \mathrm{~mm}$ and an average annual temperature of approximately $23.3^{\circ} \mathrm{C}$.

Table 3. Descriptive statistics.

\begin{tabular}{cccccc}
\hline Variable & Observations & Average & $\begin{array}{c}\text { Standard } \\
\text { deviation }\end{array}$ & Minimun & Maximun \\
\hline Y & 4.3620 & $16,141.61$ & $27,639.82$ & 301.00 & $305,540.00$ \\
Labor & 4.3620 & $1,935.52$ & $2,340.56$ & 21.00 & $43,736.00$ \\
Technology & 4.3620 & 197,53 & 344,28 & 3.00 & $5,791.00$ \\
Expenses & 4.3620 & $7,213.22$ & $11,840.34$ & 1.00 & $397,199.00$ \\
with inputs & 4.3620 & $16,141.61$ & $23,540.40$ & 50.00 & $429,428.00$ \\
Area & 4.3620 & 77.91 & 188,29 & 1.00 & $3,564.00$ \\
Irrigation & 4.3620 & 150.04 & 198,99 & 1.00 & $3,050.00$ \\
Technical & & & & & \\
assistance & & &
\end{tabular}

\footnotetext{
${ }^{7}$ It is important to highlight that Wang \& Schmidt (2002) indicates that two-steps estimation in SPF models generates biased coefficients. However, the procedures that we performed in this work cannot be considered as two-step estimates, since we are only carrying out a process of choosing between two functional forms. Although this work does not perform estimates in two-steps, it is also important to note that W ang \& Schmidt (2002) highlights that the bias in two-steps SPF estimates is generally related to the omission of $z$ in the first step. In this work, both functional forms consider the presence of $z$.
} 


\begin{tabular}{cccccc} 
Rural credit & 4.3620 & $4,868.66$ & $7,814.52$ & 1.79 & $804,501.08$ \\
Precipitation & 4.3620 & $1,328.25$ & 572.19 & 159.40 & $3,099.80$ \\
Temperature & 4.3620 & 23.25 & 3.20 & 15.21 & 33.35 \\
\hline
\end{tabular}

Source: Elaborated by the authors.

Descriptive statistics for Brazilian regions are available in the appendix. Figure 1 shows the density graphs for two of the variables used in this research, production, and technology. The left side of the figure shows the density of family farming production according to Brazilian regions. It is possible to observe that the Northeast region has the largest number of municipalities with production between $R \$ 0.00$ and $R \$ 20$ million, while the South region has the lowest number of municipalities with this same level of production. The Brazilian family farming production has a positive asymmetry, so that, as the value of production increases, the number of municipalities with these levels of production is lower, so that the highest levels of production occur, mostly, in the municipalities of the South and Midwest regions.

The right side of Figure 1 shows the density of the distribution of Brazilian family farming technology according to the region of location. The graphs show that the Northeast region has the largest number of municipalities with a technology level close to zero. On the other hand, the South region has the largest number of municipalities with the highest levels of technology. Besides, it is easy to see that technology in a less asymmetric distribution among Brazilian municipalities in comparison to the value of production, which may indicate that some regions can convert technology into production more efficiently than other regions.

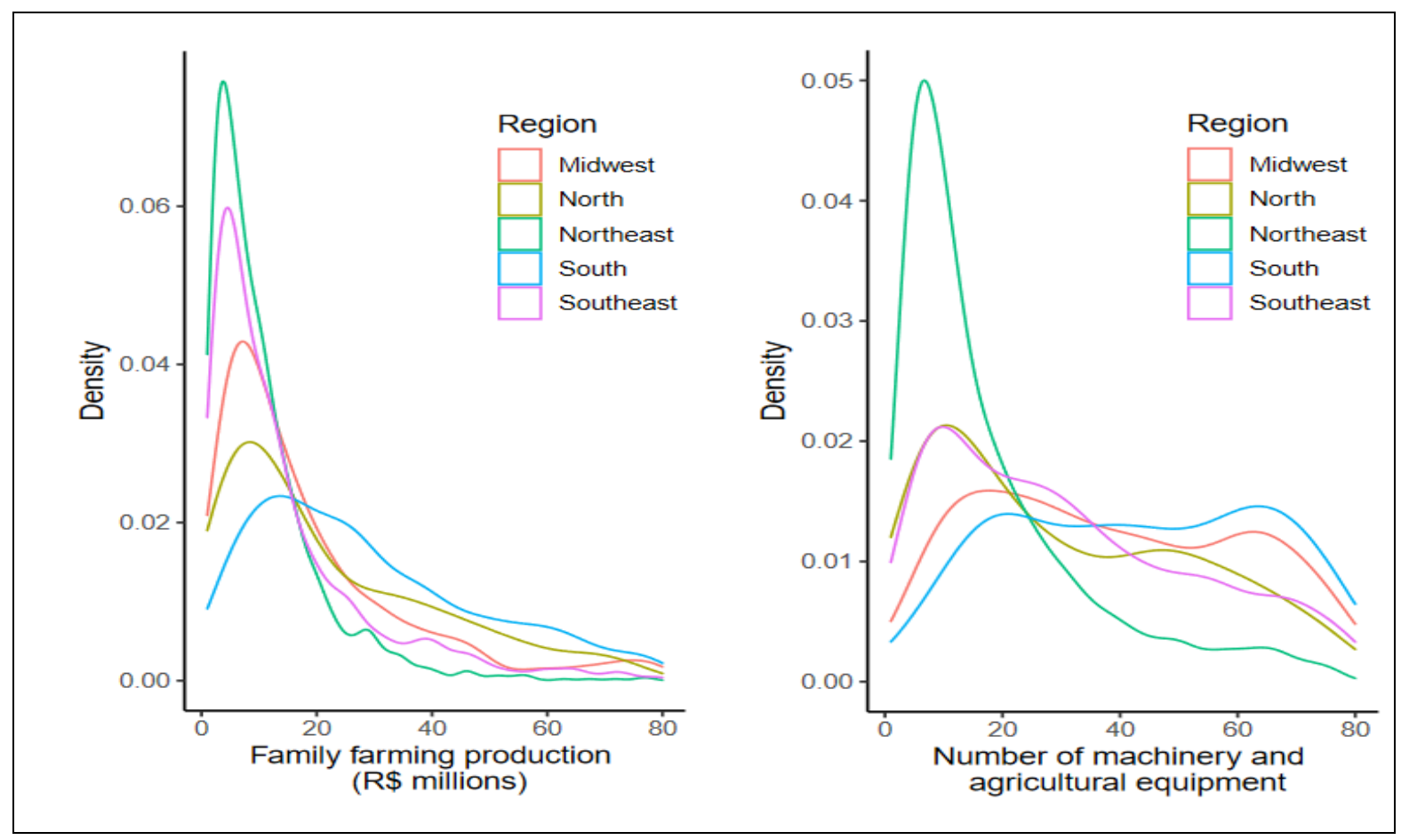

Figure 1. Kernel density for technology and production of the Brazilian family farming Source: Elaborated by the authors according to IBGE (2017). 


\subsection{Results of the Spatial Stochastic Frontiers for Family Farming}

This section presents the results obtained with the estimation of the equations 1 and 5 according to estimation techniques proposed by Battese \& Coelli (1995). To estimate these equations, we test which model is most appropriate to answer the questions presented in the introductory section (Equation 1 or Equation 5). For this, we estimate the Equation 1 using Ordinary Leasts Squares (OLS) and check if the residues of this estimation have a problem of spatial autocorrelation $^{8}$.

Based on this result, the next step was to verify if a specification of an SLX model is most appropriate than a conventional SPF specification. For this, we estimate the Equation 5 using OLS and we use a Wald test to check the null hypothesis $\theta=0$ and $\eta=0$. To test these hypotheses, we consider a spatial weights matrix calculated according the $k$ nearest neighbor method. We consider six matrices, so that each matrix has a specific value to $k^{9}$.

After verifying the viability of an SPF with the specification of an SLX model, the next step was to estimate Equation 5 by maximum likelihood. For that, we estimate one model for each spatial weights matrix, and we use the maximum log-likelihood criteria to select the most robust model.

\subsubsection{Results for Brazil}

Initially, we estimate six spatial SPF models using the total sample of Brazilian municipalities and considering $\mathrm{k}=1,2,3,4,5$ and 10 neighbors. These results are made available in Table 4 . Choosing the model with the maximum likelihood $\log (\mathrm{k}=10)$ it is possible to observe that both in the conventional model and in the SLX model, the coefficients of the non-spatially lagged variables have the same sign.

Estimates of stochastic frontiers for Brazil show that the variable expenditure on inputs had a greater influence in relation to the gross value of family farming production. However, when analyzing the stochastic spatial frontier, it is possible to notice that the number of tractors, machines, and equipment adds less production to family establishments. This result demonstrates that Brazilian family farming is more labor-intensive when compared to technology. Regarding elasticities, only the elasticity of expenditure on inputs decreases when we insert the spatially lagged variables.

Generally, the returns to scale for Brazilian agriculture are at least constant, as shown by

8 The results shown in Table 7 show that it is not possible to reject the null hypothesis that I $=0$, indicating that an estimation of SPF using OLS would cause a problem of spatial autocorrelation in the residues. As a consequence of this, the results would show that the technical inefficiency of Brazilian family farming has a spatial dependence, affecting the true coefficients of SPF and leading to misleading conclusions.

9 The results (see Table 8 in the appendix) show that disregarding the Northern region, all null hypotheses were rejected for all types of matrices, indicating that an SPF with an SLX model specification is preferable to a conventional SPF. Concerning the Northern region, the SLX model is applicable only when $\mathrm{k}=4,5$, or 10 . 
Imori et al. (2012). Analyzing the technical efficiency of rural establishments for Brazil and its regions, these authors found increasing returns to scale for all estimated stochastic frontier models. In another case, Felema et al (2013) measured labor and land productivity in Brazil and found that $57.69 \%$ of Brazilian states had constant returns to scale for the gross value of production. However, the elasticities estimated in that study showed that family farming establishments have decreasing returns.

In this work, the estimates obtained for the spatially outdated variables demonstrate that there is a negative local overflow of technology and the area destined for production. In other words, the increase in the use of these variables in a specific municipality reduces the production of family farming in neighboring municipalities. The coefficient obtained with the planted area indicates that an increase of $1 \%$ in the area used by family farming in a specific municipality can reduce the gross value of production in neighboring municipalities by $8.21 \%$. The same interpretation can be applied to technology. As this variable obtained a negative sign and was statistically significant, the value of the coefficient shows that the higher technological level of a given municipality can decrease the gross value of production in neighboring municipalities, given that the technology acts directly on production. An opposite result was found for expenditure on inputs, where the increase of $1 \%$ in the use of this factor in a specific municipality causes an increase of $10.04 \%$ in the gross income of family farming in neighboring municipalities.

Regarding the variables that determine inefficiency, it is possible to observe that while all variables in the conventional model were statistically significant, in the spatial model, temperature and precipitation did not affect the technical inefficiency of producers. However, when we analyze the determinants of inefficiency with spatially lagged variables, only the temperature was not statistically significant, indicating that rural credit, technical assistance, irrigation, and precipitation are factors that act to reduce inefficiency. It is also possible to observe a positive local overflow in the variables rural credit and irrigation, a negative overflow in the variables technical assistance, and precipitation. In other words, the increase in the use of rural credit and irrigation systems in a given municipality generates increases in the productive inefficiency of neighboring municipalities. The results also demonstrate that greater access to technical assistance and a higher level of precipitation contributes to improving the productive performance of neighboring municipalities.

Table 4. Estimates for Brazil.

\begin{tabular}{|c|c|c|c|c|c|c|c|}
\hline & $\begin{array}{c}\text { Conventional } \\
\text { SPF }\end{array}$ & $\begin{array}{c}\text { Spatial } \\
\text { SPF K } \\
=1\end{array}$ & $\begin{array}{c}\text { Spatial } \\
\text { SPF K } \\
=2\end{array}$ & $\begin{array}{c}\text { Spatial } \\
\text { SPF K = } \\
3\end{array}$ & $\begin{array}{c}\text { Spatial } \\
\text { SPF K = } \\
4\end{array}$ & $\begin{array}{c}\text { Spatial } \\
\text { SPF K = } \\
5\end{array}$ & $\begin{array}{c}\text { Spatial } \\
\text { SPF K = } \\
10\end{array}$ \\
\hline Intercept & $3.0207 *$ & $3.2549^{*}$ & $3.2302 *$ & $3.2290 *$ & $3.2670^{*}$ & $3.2990 *$ & $3.4167^{*}$ \\
\hline Ln(Area) & $0.0518 *$ & $0.0891 *$ & $0.1135^{*}$ & $0.1105^{*}$ & $0.1187 *$ & $0.1165^{*}$ & $0.1100^{*}$ \\
\hline Ln(Technology) & $0.0939 *$ & $0.2690 *$ & $0.0805^{*}$ & $0.0831 *$ & $0.0902 *$ & $0.0899 *$ & $0.0956^{*}$ \\
\hline Ln(Labor) & $0.2396^{*}$ & $0.4523^{*}$ & $0.2663^{*}$ & $0.2674^{*}$ & $0.2577^{*}$ & $0.2593 *$ & $0.2566^{*}$ \\
\hline $\begin{array}{l}\text { Ln(Expenses with } \\
\text { inputs) }\end{array}$ & $0.5029 *$ & $0.4523^{*}$ & $0.4373^{*}$ & $340^{*}$ & $0.4307 *$ & $0.4340^{*}$ & $0.4418 *$ \\
\hline $\mathrm{W}[\operatorname{Ln}($ Area $)]$ & - & $-0.0464 *$ & $-0.0791 *$ & $-0.0754 *$ & $-0.0879 *$ & $-0.0855^{*}$ & $-0.0821 *$ \\
\hline $\mathrm{W}[\operatorname{Ln}($ Technology $)]$ & - & -0.0030 & -0.0127 & -0.0209 & $-0.0347 *$ & $-0.0360 *$ & $-0.0555^{*}$ \\
\hline $\mathrm{W}[\mathrm{Ln}($ Labor $)]$ & - & $-0.0370^{*}$ & -0.0356 & -0.0406 & -0.0319 & -0.0337 & -0.0340 \\
\hline $\begin{array}{l}\mathrm{W}[\operatorname{Ln}(\text { Expenses with } \\
\text { inputs) }]\end{array}$ & - & $0.0618 *$ & $0.0946^{*}$ & $0.1046^{*}$ & $0.1132 *$ & $0.1072 *$ & $0.1004 *$ \\
\hline
\end{tabular}




\section{Macrothink}

Journal of Agricultural Studies

ISSN 2166-0379

2021, Vol. 9, No. 3

\begin{tabular}{|c|c|c|c|c|c|c|c|}
\hline Z_Intercept & $2.5324^{*}$ & $3.1330^{*}$ & $3.2090^{*}$ & $3.2117^{*}$ & $3.3007^{*}$ & $3.3562^{*}$ & $3.3964^{*}$ \\
\hline Z_Ln(Rural Credit) & $-0.0185^{*}$ & $-0.0290 *$ & $-0.0309^{*}$ & $-0.0334 *$ & $-0.0326^{*}$ & $-0.0324 *$ & $-0.0352 *$ \\
\hline $\begin{array}{l}\text { Z_Ln(Techincal } \\
\text { Assistance) }\end{array}$ & $-0.0500 *$ & $-0.0530 *$ & $-0.0441 *$ & $-0.0444 *$ & $-0.0409 *$ & $-0.0382 *$ & $-0.0358 *$ \\
\hline Z_Ln(Irrigation) & $-0.0262 *$ & $-0.0395 *$ & $-0.0442 *$ & $-0.0444 *$ & $-0.0471 *$ & $-0.0479 *$ & $-0.0524 *$ \\
\hline Z_Ln(Temperature) & $0.3388^{*}$ & -0.0553 & -0.2845 & -0.0246 & 0.0020 & 0.0191 & -0.0584 \\
\hline Z_Ln(Precipitation) & $-0.4201 *$ & $-0.0284 *$ & $-0.1500^{*}$ & -0.1258 & -0.1358 & -0.1000 & -0.0704 \\
\hline Z_W[Ln(Rural Credit)] & & 0.0143 & $0.0268^{*}$ & $0.0367^{*}$ & $0.0383^{*}$ & $0.0374 *$ & $0.0489^{*}$ \\
\hline $\begin{array}{c}\text { Z_W[Ln(Techincal } \\
\text { Assistance) }]\end{array}$ & - & -0.0161 & $-0.0363^{*}$ & $-0.0409^{*}$ & $-0.0554 *$ & $-0.0637^{*}$ & $-0.0829 *$ \\
\hline Z_W[Ln(Irrigation)] & - & 0.0159 & $0.0253^{*}$ & $0.0265^{*}$ & $0.0335^{*}$ & $0.0365 *$ & $0.0521^{*}$ \\
\hline $\mathrm{Z}_{-} \overline{\mathrm{W}}[\mathrm{Ln}$ (Temperature $\left.)\right]$ & - & 0.3674 & 0.5650 & 0.2964 & 0.2468 & 0.2379 & 0.3201 \\
\hline Z_W[Ln(Precipitation)] & - & $-0.1932 *$ & $-0.3252 *$ & $-0.3499 *$ & -0.3390 & $-0.3829 *$ & $-0.4214 *$ \\
\hline Average efficiency & 0.8344 & 0.7418 & 0.7454 & 0.7402 & 0.7357 & 0.7344 & 0.7221 \\
\hline Log likelihood & $-1,536.3750$ & -1.4650 & -1.4370 & -1.4390 & -1.4370 & -1.4339 & -1.4139 \\
\hline
\end{tabular}

Source: Elaborated by the authors.

Note: * indicates statistical significance at $95 \%$ confidence level.

\subsubsection{Results for Brazilian Regions}

Unlike the analysis made for Brazil, the results of the estimates for the regions were analyzed based only on the best estimated spatial SPF model, shown in Table 4. In general, the area, technology, labor, and input expenses cause a positive effect.

According to the results, the returns to scale for each region were constant. However, the Midwest (0.96), followed by the Southeast (0.943) and the South (0.9408), obtained a better return of scale when compared to the North (0.7888) and Northeast (0.749). Com- paring the spatial and the conventional models it is possible to notice that even if the local spatial dependence is not considered, the North and Northeast regions present a lower scale return compared to the other regions. This result can be justified by the reduced access to machinery, equipment, tractors, and agricultural implements, as shown in Table 1.

Disregarding the North and Northeast regions, input expenses have a greater influence on the production value. The results show that the $1 \%$ increase in this production factor caused an increase of $49.51 \%, 48.58 \%, 46.60 \%, 32.85 \%$, and $28.24 \%$ in the gross production value of family farming establishments in the Midwest, Southeast, Northeast, South, and North regions, respectively.

Land destined for the production of family farming establishments was, in general, the production factor with less relevance over the gross value of production. On the other hand, technology, as expected, had a greater effect in the South $(25.03 \%)$, in contrast to the Northeast (4.66\%). These results corroborate with Hoffmann (1992), Vieira Filho (2014) and Felema et al. (2013). These authors indicated that the modernization process of Brazilian agriculture was initially implemented in the South and Southeast regions of the country and that family farmers in these areas have become technologically more advanced than farmers in other regions, especially in relation to family farmers in the Northeast, region which is characterized by having a large number of family farmers with subsistence practices and with greater demand for technological assistance.

Thus, although the Northeast is more labor-intensive compared to technology, the elasticity of labor was also greater in the South, that is, despite having a smaller number of employed 
persons, in the South region workers can add more value to the income of family farming establishments. However, when there is a positive variation of $1 \%$ in labor, the gross value of production tends to have a greater effect in the Southeast $(35.2 \%)$, followed by the North (31.7\%), South (21\%), Midwest (20.36\%) and Northeast (11.84\%).

Analyzing the coefficients of the spatially lagged variables, it is possible to notice that the North region has a positive spatial spillover of labor, indicating that the increase of this production factor in family farming in a specific municipality increases the production of family farming in neighboring areas. The results also show that the gross value of production in a specific municipality in the North region decreases, to the detriment of land use in family farming in neighboring municipalities.

For Northeast and Southeast regions ${ }^{10}$, The results show that the variables that determine the production of family farming do not have a local spatial spillover between the municipalities. This result provides evidence that family farming operates only with local resources, not absorbing capital, labor, or technology from the most specialized municipalities in the same region.

On the other hand, the South and Midwest regions of Brazil ${ }^{11}$ had a negative local spatial spillover for the variables area and technology, indicating that the increase in these production factors in a specific municipality reduces the gross value of production in the neighboring areas of these regions.

The results also show that there was a positive local spillover for the variable expen- diture on inputs so that this effect is higher for the Midwest. Besides, the results indicate that there are positive spillovers of work only for the South region, demonstrating that the greater use of this production factor in a specific municipality causes an increase in the gross value of production in the neighboring areas. It is important to highlight that the Midwest region does not have local spillover effects for the labor.

Regarding the variables that capture the inefficiency, the results show that not all regions have effects from changes in the exogenous variables used in the model: (i) North: rural credit and irrigation mitigate inefficiency; (ii) Northeast: although rural credit does not affect the production efficiency, technical assistance and irrigation reduce inefficiency, so that the effects of irrigation is higher when compared with technical assistance; (iii) Southeast: no explanatory variable affects the production; (iv) South: the only variable that had a local spatial spillover was access to technical assistance. According to the results, this variable reduces the inefficiency in the region; (v) Midwest: The only variable that showed statistical significance was rural credit, showing a positive relationship with technical inefficiency. Besides, it was also possible to observe that variations in temperature and precipitation do not affect the technical inefficiency of family farming in any of the regions. Finally, the analysis

\footnotetext{
${ }^{10}$ In these regions, the model with $\mathrm{k}=10$ had the maximum value for the log-likelihood.

11 The model with maximum likelihood value was obtained with $\mathrm{k}=4$ and $\mathrm{k}=5$ for South and Midwest regions, respectively.
} 
of the determinants of inefficiency with the spatially lagged variables allows us to conclude that access to rural credit was not statistically significant for any of the regions. This result indicates that there are no local spatial spillovers for the relationship between rural credit and technical inefficiency.

In the South, the determinants of spatially lagged inefficiency were not statistically significant. The results also show that disregarding the South region, the spillover effect of temperature on technical inefficiency is superior to the other coefficients of spatially lagged variables. Concerning technical assistance, while the North shows a negative spillover over inefficiency, for the Southeast, this relationship is positive; the opposite is true for irrigation, where the increased use of irrigation in the North region increases the productive inefficiency of neighboring municipalities. In the Southeast, the spillover effect of irrigation occurs oppositely. Precipitation shows negative spillovers in the Northeast and Southeast, indicating that an increase in the level of rainfall in a specific municipality in these regions reduces the technical inefficiency of family farming in neighboring municipalities.

Table 5. Estimates for Brazilian regions

\begin{tabular}{|c|c|c|c|c|c|c|c|c|c|c|}
\hline \multirow[t]{3}{*}{ Estimates } & \multicolumn{2}{|c|}{ North } & \multicolumn{2}{|c|}{ Northeast } & \multicolumn{2}{|c|}{ Southeast } & \multicolumn{2}{|c|}{ South } & \multicolumn{2}{|c|}{ Midwest } \\
\hline & Conventional & Spatial & Conventional & Spatial & Conventional & Spatial & Conventional & Spatial & Conventional & Spatial \\
\hline & SPF & SPF & SPF & SPF & SPF & SPF & SPF & SPF & SPF & SPF \\
\hline Intercept & $3.2730^{*}$ & $4.2134^{*}$ & $3.9400^{*}$ & $4.6000^{*}$ & $2.4921^{*}$ & $2.5087^{*}$ & $4.0409^{*}$ & $0.5507^{*}$ & $2.5289^{*}$ & $2.3083^{*}$ \\
\hline $\ln$ (Area) & 0.0802 & $0.1894^{*}$ & $0.0684^{*}$ & $0.1180^{*}$ & 0.0048 & 0.0475 & -0.0214 & $0.1520^{*}$ & 0.0204 & $0.1240^{*}$ \\
\hline $\ln ($ Technology) & 0.0609 & 0.0520 & $0.0592^{*}$ & $0.0466 *$ & $0.1071^{*}$ & $0.1052^{*}$ & $0.1766^{*}$ & $0.2503^{*}$ & $0.1042^{*}$ & $0.1373^{*}$ \\
\hline $\ln ($ Labor $)$ & $0.4122 *$ & $0.3170^{*}$ & $0.0168^{*}$ & $0.1184^{*}$ & $0.3387^{*}$ & $0.3520^{*}$ & $0.2948^{*}$ & $0.2100^{*}$ & $0.1934 *$ & $0.2036^{*}$ \\
\hline $\begin{array}{l}\ln (\text { Expenses with } \\
\text { inputs) }\end{array}$ & $0.3228^{*}$ & $0.2824^{*}$ & $0.4600^{*}$ & $0.4660^{*}$ & $0.5238^{*}$ & $0.4858^{*}$ & $0.3980^{*}$ & $0.3285^{*}$ & $0.6188^{*}$ & $0.4951^{*}$ \\
\hline $\mathrm{W}[\ln ($ Area $)]$ & - & $-0.3054^{*}$ & - & -0.0392 & - & -0.0767 & - & $-0.3312^{*}$ & - & $-0.1226^{*}$ \\
\hline $\mathrm{W}[\ln ($ Technology $)]$ & - & 0.0026 & - & 0.0197 & - & 0.0034 & - & $-0.1047 *$ & - & $-0.1020^{*}$ \\
\hline $\mathrm{W}[\ln ($ Labor $)]$ & - & $0.2822^{*}$ & - & 0.0855 & - & -0.0108 & - & $0.1886^{*}$ & - & -0.0711 \\
\hline $\begin{array}{c}\mathrm{W}[\ln (\text { Expenses with } \\
\text { inputs) }]\end{array}$ & - & 0.0110 & - & -0.0385 & - & 0.0602 & - & $0.1922^{*}$ & - & $0.2510^{*}$ \\
\hline \multicolumn{11}{|c|}{ Determinants of inefficiency } \\
\hline Z_Intercept & 2.0421 & 0.0609 & $2.4000^{*}$ & 1.1800 & $6.0084^{*}$ & 0.6883 & $1.5978^{*}$ & $28.6622^{*}$ & -30.5971 & -43.7235 \\
\hline Z_Ln(Rural Credit) & $-0.0808^{*}$ & $-0.0865^{*}$ & -0.0289 & -0.0283 & 0.0088 & 0.0019 & $-0.0327^{*}$ & 0.0187 & -0.4202 & $-0.2474 *$ \\
\hline $\begin{array}{l}\text { Z_Ln(Techincal } \\
\text { Assistance) }\end{array}$ & -0.0560 & -0.0571 & $-0.0636^{*}$ & $-0.0536^{*}$ & 0.0108 & 0.0090 & $-0.1403 *$ & $-0.4900^{*}$ & 0.0040 & 0.0462 \\
\hline Z_Ln(Irrigation) & $-0.0924 *$ & $-0.1272 *$ & $-0.0588^{*}$ & $-0.0759^{*}$ & $-0.0786^{*}$ & -0.0253 & $0.0354^{*}$ & -0.0399 & -0.1716 & -0.1297 \\
\hline Z_Ln(Temperature) & 1.8250 & 0.1915 & 0.3860 & -0.0664 & $2.7762^{*}$ & 0.0378 & $-0.4886^{*}$ & -2.1251 & 3.6912 & -2.7200 \\
\hline Z_Ln(Precipitation) & -0.3663 & -0.4628 & -0.3660 & -0.0622 & $-2.1546^{*}$ & -0.2729 & - & -0.1942 & 2.8247 & 1.7873 \\
\hline$Z_{-} W[$ Ln(Rural Credit)] & - & 0.0297 & - & 0.0285 & - & 0.0193 & - & -0.4198 & - & 0.6010 \\
\hline $\begin{array}{c}\text { Z_W[Ln(Techincal } \\
\text { Assistance) }]\end{array}$ & - & $-0.3176^{*}$ & - & -0.0408 & - & $0.1400^{*}$ & - & -0.0705 & - & 0.0746 \\
\hline Z_W[Ln(Irrigation)] & - & $0.3650^{*}$ & - & -0.0458 & - & $-0.0816^{*}$ & - & 0.6093 & - & 0.0346 \\
\hline Z_W[Ln(Temperature)] & - & $0.8497^{*}$ & - & $1.4700^{*}$ & - & $3.8035^{*}$ & - & -1.6006 & - & $10.1490^{*}$ \\
\hline Z_W[Ln(Precipitation)] & - & -0.2568 & - & $0.1340^{*}$ & - & $-1.6643^{*}$ & - & -1.7969 & - & 1.6526 \\
\hline Sigma2 & $0.1399^{*}$ & $0.1204 *$ & $0.1450^{*}$ & 1.0000 & $0.1497^{*}$ & $0.0989 *$ & $0.0810^{*}$ & $0.2131^{*}$ & 0.2151 & $0.1314^{*}$ \\
\hline Gamma & $0.4005^{*}$ & $0.4465 *$ & 1.0000 & 0.6155 & $0.3795 *$ & $1.0000^{*}$ & $0.1674 *$ & $0.6951 *$ & $0.6491 *$ & 0.4414 \\
\hline Average efficiency & 0.7543 & 0.7095 & 0.6053 & -428.2000 & -400.1885 & 0.9649 & 0.7328 & 0.9243 & 0.9026 & 0.9346 \\
\hline Log likelihood & -101.6836 & -83.4052 & -466.2000 & & & -372.0329 & -176.2801 & -122.7466 & -82.6163 & -62.6746 \\
\hline
\end{tabular}

Source: Elaborated by the authors.

Note (1): * indicates statistical significance at $95 \%$ confidence level.

Note (2): The spatial SPF estimates was made using a spatial weights matrix with $\mathrm{k}=1, \mathrm{k}=2, \mathrm{k}=3, \mathrm{k}=4, \mathrm{k}=5$ and $\mathrm{k}=10$. According to the $\log$ likelihood of each estimation, the most adequate estimates for regions North, Northeast and Southeast were made using $\mathrm{k}=10$. In the models for regions South and Midwest we use $\mathrm{k}=4$ and $\mathrm{k}=10$, respectively. 


\subsection{Technical Efficiency for Brazilian Regions}

After estimating the SPF for each specified territorial level, the next step was to obtain the efficiency scores according to Equation 6. The results of this procedure are shown in Figure $2^{12}$.

Analyzing Figure 2a, it is possible to observe that there is a higher concentration of more efficient municipalities in the South and Southeast regions, in the West of the state of Mato Grosso and in the South-Central and East of the Southeast region. The results also show that the lowest efficiency scores are more concentrated along the North of the state of Minas Gerais and in the Central part of the Northeast region. This pattern of distribution of efficiency scores is an expected result since the large centers of agricultural technology in Brazil are located in the South, Southeast, and Midwest of Brazil. Although the technology of the agricultural sector is widely applied in agribusiness in these regions, it is possible that family farming is absorbing the technology used in the large agricultural establishments in these areas, which would explain the high levels of efficiency of family farming in the municipalities mentioned.

To reinforce this evidence, we used the results obtained by Souza et al. (2019), where the authors demonstrated that the highest levels of technology use in Brazilian family farming are located in the South, Southeast, and Midwest regions. On other hand, according to the authors, in the North and Northeast regions, the use of technology by family farmers generally occurs at low or very low levels. Despite having a great impact on the technical efficiency of Brazilian family farming, we cannot consider the use of technology as the only or main determinant of the efficiency scores found in this study, since, Souza et al. (2019) also highlight that the technological profile of family farming in Brazilian municipalities is an adaptation of farmers to a series of other factors, such as the relative endowment of land, the qualification of labor, access to financial resources and the policy of credit, regional infrastructure, and others.

When the efficiency scores are analyzed individually for each region of Brazil, it is possible to see that the South and Midwest regions have a high predominance of municipalities where the production of family farming occurs at a level close to the production possibility frontier. In addition to production technology, a large number of municipalities with high-efficiency scores in these regions can be explained by the concentration of rural credit. Souza et al. (2019) demonstrate that among Brazilian regions, there is a large concentration of financing for rural activities in the Midwest region. The authors also demonstrate that, among the other areas, the South region has the highest percentage of rural credit for small producers.

While the South, Midwest, and South-Central of the Southeast have a high concentration of observations with efficiency scores close to the unit, the Northeast, North, and North parts of the Southeast contain the highest concentrations of less-efficient municipalities. This is an expected result since the climatic profile of the Northeast and North of the Southeast of Brazil $^{13}$ hinders the productivity gains of agricultural activities. Besides, Assunção and Chein

12 The efficiency scores were calculated according to the SLX models presented in Table 5.

${ }^{13}$ In most municipalities located in these areas, the climate is predominantly semi-arid. 


\section{MInstitute ${ }_{\text {Mnk }}^{\text {Macrothink }}$}

(2016) demonstrated that the greatest productivity losses in Brazilian agriculture associated with climate change occur, in the majority, in the municipalities of the North and Northeast regions.

In the North region, the states of Rondônia and Pará have most of the municipalities with the highest levels of efficiency. On the other hand, the municipalities with the lowest efficiency scores belong to the states of Tocantins and Roraima. It is important to highlight that the low logistical infrastructure of many municipalities in the region can make access to technologies and means of production difficult, which causes a loss of competitiveness and difficulty in obtaining gains in productivity and technical efficiency. Besides, the environ- mental policy applied in some municipalities in the region may prevent the adoption of new production technologies, which can generate a relative loss of efficiency in family farming in these municipalities.

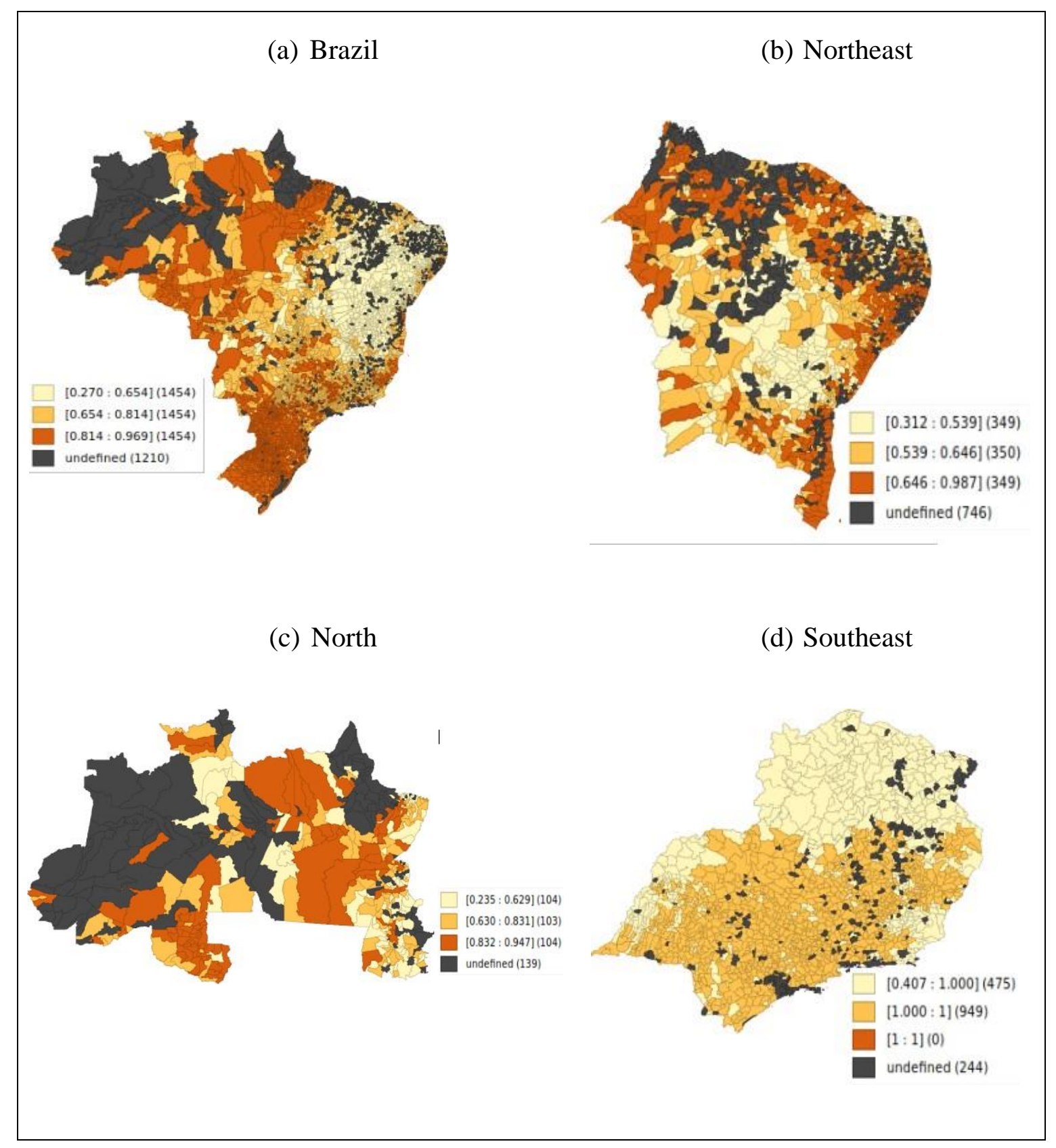




\section{Macrothink}

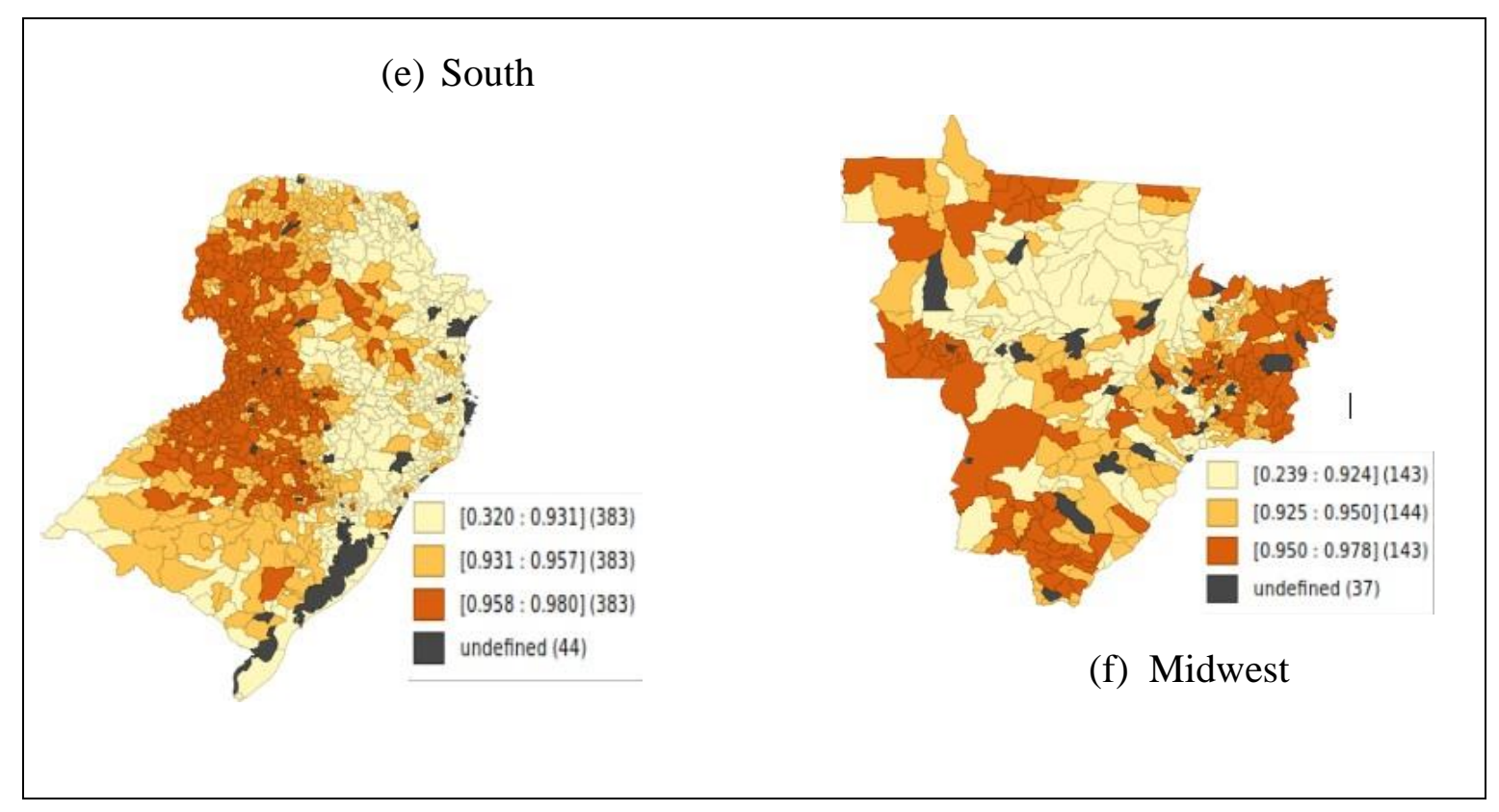

Figure 2. Efficiency scores for Brazilian regions

Source: Elaborated by the authors.

Note: Undefined represents non-considered municipalities.

In summary, regarding the efficiency scores, the analyzes made for Brazilian municipalities differ little from the results obtained with the estimates at the regional level. The regions South, Midwest, and South-Central of the Southeast region present a large concentration of municipalities with high scores, while the lowest levels of efficiency were obtained by the municipalities in the Northeast, North and in the North part of the Southeast region.

It is important to highlight that some factors not observed can act as determinants of heterogeneity, such as resident population (see Table 11), technological limitations and infrastructure, and the type of planting in which each region specialized (see tables 9 and 10). Thus, it is expected that spatial heterogeneity is not fully captured by the factors observed in the stochastic border model. However, as a result of the method used, this heterogeneity is probably not sufficient to change the direction of the signals of the parameters found and the relative position of the efficiency scores of each municipality.

\section{Concluding Remarks}

Considering the concentration of family farmers that compose Brazilian agriculture and the productive heterogeneity existing between the regions of the country, this study contributes to the existing literature, being a pioneer in measuring the technical efficiency of family farmers in Brazil and Brazilian regions. For this, we use a spatial stochastic frontier analysis based on the most recent census information in Brazil.

The results obtained in the descriptive statistics and the stochastic borders corroborate with the existing literature since, from these results, it was possible to verify that there are significant differences between the gross values of production in the Brazilian regions. 
Furthermore, these regional differences were also confirmed by returns to scale of production. The results showed that all regions have decreasing returns. Besides, we also found that the scale of production is greater for the Midwest, Southeast, and South regions.

In general, compared to the area considered for production, expenditure on inputs had the most influence on the increase of the gross value of family agriculture production. In line with the literature, technology had the most effect on the value of family farming production in the South, while the least effect occurs in the Northeast. The results also showed that although the Northeast region is more labor-intensive, a positive variation in this variable also has a lesser effect on the gross income of family farmers, showing that in the other areas, workers contribute more to the production of family farming. This result may be due to the asymmetric modernization process of Brazilian agriculture, where the South, Southeast, and Midwest regions were more capitalized and, consequently, obtained the most human capital levels.

The local spatial spillover effects occur in different ways for both the factors of pro- duction and the determinants of inefficiency. Labor and input expenses generate a positive spatial spillover in the production, while area and technology generate negative spillovers. It is also possible to conclude that rural credit does not generate spatial spillovers on the inefficiency of family farmers. Finally, we conclude that the regions South, Midwest, and South-Central of the Southeast have the highest efficiency scores, while the lowest levels of efficiency occur in the Northeast, North, and North parts of the Southeast region.

Therefore, it is necessary that these policies are efficiently implemented or that they are applied, for the most part, in the North and Northeast regions of Brazil (Some policies already have this profile, such as Pronaf and many technical assistance policies). Besides, the policies applied to Brazilian family farming must seek to minimize these differences, always taking into account the individual characteristics of each region for the better effectiveness of these policies.

\section{References}

Abramovay, R. (1997). Agricultura familiar e uso do solo. São Paulo em perspectiva, 11(2), 73-78.

Adetutu, M., Glass, A. J., Kenjegalieva, K., \& Sickles, R. C. (2015). The effects of efficiency and tfp growth on pollution in Europe: a multistage spatial analysis. Journal of Productivity Analysis, 43(3), 307-326. https://doi.org/10.1007/s11123-014-0426-7

Aigner, D., Lovell, C. K., \& Schmidt, P. (1977). Formulation and estimation of stochastic frontier production function models. Journal of econometrics, 6(1), 21-37. https://doi.org/10.1016/0304-4076(77)90052-5

Ajibefun, I. A., Daramola, A. G., \& Falusi, A. O. (2006). Technical efficiency of small-scale farmers: An application of the stochastic frontier production function to rural and urban farmers in Ondo state, Nigeria. International economic journal, 20(1), 87-107. https://doi.org/10.1080/10168730500515498 


\section{Macrothink}

Journal of Agricultural Studies

ISSN 2166-0379

2021, Vol. 9, No. 3

Almeida, J. (2011). A modernização da agricultura, Editora da UFRGS. (Série Educação a Distância).

Almeida, P. N. A. (2012), Fronteira de produção e eficiência técnica da agropecuária brasileira em 2006, PhD theses, Universidade de São Paulo.

Aquino, J. R. D., Gazolla, M., \& Schneider, S. (2018). Dualismo no campo e desigualdades internas na agricultura familiar brasileira. Revista de Economia e Sociologia Rural, 56(1), 123-142. https://doi.org/10.1590/1234-56781806-94790560108

Assunção, J., \& Chein, F. (2016). Climate change and agricultural productivity in Brazil: future perspectives. Environment and Development Economics, 21(5), 581-602. https://doi.org/10.1017/S1355770X1600005X

Battese, G. E., \& Coelli, T. J. (1995). A model for technical inefficiency effects in a stochastic frontier production function for panel data. Empirical economics, 20(2), 325-332. https://doi.org/10.1007/BF01205442

Binam, J., Tonye, J., \& Wandji, N. (2005). Source of technical efficiency among smallholder maize and peanut farmers in the slash and burn agricultural zone of cameroun. Journal of Economic Cooperation, 26(1), 193-210.

BRASIL (2006). Lei $n^{\circ} 11.326$, de 24 de julho de 2006. Estabelece as diretrizes para a formulação da política nacional da agricultura familiar e empreendimentos familiares rurais. Available in: http://www.planalto.gov.br/ccivil_03/_Ato2004-2006/2006/Lei/L11326.htm.(Accessed: 09.08.2020).

Brasiliense. G. C. E. (2001), Agricultura familiar e reforma agrária no século XXI, Editora Garamond.

Bravo-Ureta, B. E., \& Evenson, R. E. (1994). Efficiency in agricultural production: the case of peasant farmers in eastern Paraguay. Agricultural economics, 10(1), 27-37. https://doi.org/10.1016/0169-5150(94)90037-X

Bravo-Ureta, B. E., \& Pinheiro, A. E. (1997). Technical, economic, and allocative efficiency in peasant farming: evidence from the Dominican Republic. The developing economies, 35(1), 48-67. https://doi.org/10.1111/j.1746-1049.1997.tb01186.x

Camarillo-Naranjo, J. M., Álvarez-Francoso, J. I., Limones-Rodríguez, N., Pita-López, M. F., \& Aguilar-Alba, M. (2019). The global climate monitor system: from climate data- handling to knowledge dissemination. International Journal of Digital Earth, 12(4), 394-414. https://doi.org/10.1080/17538947.2018.1429502

CANAL RURAL (April 14, 2021). Situação preocupante: governo ainda não entendeu a importância da familiar'. Available in: https://www.canalrural.com.br/noticias/agricultura/governo-importancia-agricultura-familiar. (Accessed: 06.19.2020). 
Coelli, T. J., Rao, D. S. P., O’Donnell, C. J., \& Battese, G. E. (2005), An introduction to efficiency and productivity analysis, Springer Science \& Business Media.

Costa, E. M., \& Filho, J. E. R. V. (2018). Choque de oferta no crédito rural e seu impacto produtivo na agricultura brasileira. Políticas públicas avaliando mais de meio trilhão de reais em gastos públicos, p. 207.

de Almeida, L. F., Zylbersztajn, D., \& Klein, P. G. (2010). Determinants of contractual arrangements in agricultural credit transactions. Revista de Administração, 45(3), 209-220. https://doi.org/10.1016/S0080-2107(16)30476-9

Delgado, G. C. (2005). A questão agrária no Brasil, 1950-2003. Questão social e políticas sociais no Brasil contemporâneo. Brasília: IPEA pp. 51-90.

Felema, J., Raiher, A. P., \& Ferreira, C. R. (2013). Agropecuária brasileira: desempenho regional e determinantes de produtividade. Revista de Economia e Sociologia Rural, 51(3), 555-573. https://doi.org/10.1590/S0103-20032013000300008

Graziano, N. (1985). Ecologia: Crítica da agricultura moderna. São Paulo.

Guanziroli, C. E., \& Di Sabbato, A. (2014). Existe na agricultura brasileira um setor que corresponde ao" family farming" americano?. Revista de Economia e Sociologia Rural, 52, 85-104. https://doi.org/10.1590/S0103-20032014000600005

Guanziroli, C. E., Buainain, A. M., \& Di Sabbato, A. (2012). Dez anos de evolução da agricultura familiar no Brasil:(1996 e 2006). Revista de Economia e Sociologia Rural, 50(2), 351-370. https://doi.org/10.1590/S0103-20032012000200009

Halleck Vega, S. \& Elhorst, J. P. (2015). The slx model. Journal of Regional Science, 55(3), 339-363. https://doi.org/10.1111/jors.12188

Hoffmann, R. (1992). A dinâmica da modernização da agricultura em 157 microrregiões homogêneas do Brasil. Revista de Economia e Sociologia Rural, 30(4), 271-290.

IBGE (2017). Censo agropecuário 2017’. Available in: https://censos.ibge.gov.br/ agro/2017. (Accessed: 09.10.2020).

IBGE (2020). 'Índice de organização do território'. Available in: $\mathrm{ftp}$ //geoftp.ibge.gov.br/organizacao_do_territorio/malhas_territoriais/malhas_municipais/mu nicipio_2015/. (Accessed: 09.10.2020)

IBGE (2021). Estimativas de população'. Available in: https://sidra.ibge.gov.br/tabela/6579r.(Accessed: 06.19.2020).

Imori, D., Guilhoto, J. J. M. \& Postali, F. A. S. (2012), Eficiência técnica das agropecuárias familiar e patronal-diferenças regionais no Brasil, Munich Personal RePEc Archive.

Leite, S. P. (2001). Análise do financiamento da política de crédito rural no brasil (19801996). Estudos Sociedade e Agricultura.

Mariano, J. L., \& Pinheiro, G. M. D. T. L. (2009). Eficiência técnica da agricultura familiar 
no projeto de irrigação do Baixo Açu (RN). Revista Econômica do Nordeste, 40(2), 283-296.

Matos, P. F., \& Pessoa, V. L. S. (2011). A modernização da agricultura no brasil e os novos usos do território. Geo UERJ, 2(22), 290-322. https://doi.org/10.12957/geouerj.2011.2456

Nehring, R., Gillespie, J., Sandretto, C., \& Hallahan, C. (2009). Small us dairy farms: can they compete? Agricultural Economics, 40, 817-825. https://doi.org/10.1111/j.1574-0862.2009.00418.x

Neto, C. G. A. M., de Melo, L. M., \& Maia, C. M. (2010), Políticas públicas e desenvolvimento rural no Brasil, Editora da UFRGS.

Pede, V. O., Areal, F. J., Singbo, A., McKinley, J., \& Kajisa, K. (2018). Spatial dependency and technical efficiency: an application of a bayesian stochastic frontier model to irrigated and rainfed rice farmers in Bohol, Philippines. Agricultural economics, 49(3), 301-312. https://doi.org/10.1111/agec.12417

Scherer, C. E. M., \& Porsse, A. A. (2017). Eficiência produtiva regional da agricultura brasileira: uma análise de fronteira estocástica. Revista de Economia e Sociologia Rural, 55(2), 389-410. https://doi.org/10.1590/1234-56781806-94790550210

Schmidt, A. M., Moreira, A. R., Helfand, S. M., \& Fonseca, T. C. (2009). Spatial stochastic frontier models: accounting for unobserved local determinants of inefficiency. Journal of Productivity Analysis, 31(2), 101-112. https://doi.org/10.1007/s11123-008-0122-6

Schneider, S., Cazella, A. A., \& Mattei, L. F. (2021). Histórico, caracterização e dinâmica recente do PRONAF - Programa Nacional de Fortalecimento da Agricultura Familiar. Revista Grifos, 30(51), 12-41. https://doi.org/10.22295/grifos.v30i51.5656

Seyoum, E., Battese, G. E., \& Fleming, E. (1998). Technical efficiency and productivity of maize producers in eastern Ethiopia: a study of farmers within and outside the sasakawaglobal 2000 project. Agricultural economics, $19(3), \quad 341-348$. https://doi.org/10.1016/S0169-5150(98)00037-1

Sorj, B. (2008), Estado e classes sociais na agricultura brasileira, Centro Edelstein de Pesquisas Sociais. https://doi.org/10.7476/9788599662281

Souza, P. M. D., Fornazier, A., Souza, H. M. D., \& Ponciano, N. J. (2019). Diferenças regionais de tecnologia na agricultura familiar no brasil. Revista de Economia e Sociologia Rural, 57(4), 594-617. https://doi.org/10.1590/1806-9479.2019.169354

Teixeira, J. C. (2005). Modernização da agricultura no brasil: impactos econômicos, sociais e ambientais. Revista Eletrônica da Associação dos Geógrafos Brasileiros, Seção Três Lagoas pp. 21-42.

Tsionas, E. G., \& Michaelides, P. G. (2016). A spatial stochastic frontier model with spillovers: Evidence for Italian regions. Scottish Journal of Political Economy, 63(3), 243-257. https://doi.org/10.1111/sjpe.12081

Tsukamoto, T. (2019). A spatial autoregressive stochastic frontier model for panel data 
incorporating a model of technical inefficiency. Japan and the World Economy, 50, 66-77. https://doi.org/10.1016/j.japwor.2018.11.003

Vidoli, F., Cardillo, C., Fusco, E., \& Canello, J. (2016). Spatial nonstationarity in the stochastic frontier model: An application to the Italian wine industry. Regional Science and Urban Economics, 61, 153-164. https://doi.org/10.1016/j.regsciurbeco.2016.10.003

Vieira Filho, J. E. R. (2014). Transformação histórica e padrões tecnológicos da agricultura brasileira. O mundo rural do Brasil no século 21: a formação de um novo padrão agrário e agrícola, 395-421.

Wang, H. J., \& Schmidt, P. (2002). One-step and two-step estimation of the effects of exogenous variables on technical efficiency levels. Journal of Productivity Analysis, 18(2), 129-144. https://doi.org/10.1023/A:1016565719882

\section{Appendixes}

Table 6: Descriptive statistics for Brazilian regions.

\begin{tabular}{|c|c|c|c|c|c|}
\hline Variable & Observations & Mean & $\begin{array}{l}\text { Standard } \\
\text { deviation }\end{array}$ & Minimum & Maximum \\
\hline \multicolumn{6}{|c|}{ North } \\
\hline$Y$ & 311 & $29,023.94$ & $28,405.81$ & 900.00 & $188,723.00$ \\
\hline Labor & 311 & $3,626.16$ & $4,274.45$ & 120.00 & $43,736.00$ \\
\hline Technology & 311 & 59.03 & 54.65 & 3.00 & 333.00 \\
\hline Capital & 311 & $5,480.99$ & $5,517.71$ & 180.00 & $37,560.00$ \\
\hline Area & 311 & $52,217.74$ & $54,457.87$ & $1,905.00$ & $429,428.00$ \\
\hline Irrigation & 311 & 79.51 & 134.75 & 1.00 & $1,020.00$ \\
\hline $\begin{array}{l}\text { Technical } \\
\text { assistance }\end{array}$ & 311 & 103.56 & 106.24 & 1.00 & 582.00 \\
\hline Rural credit & 311 & $4,279.76$ & $7,609.80$ & 2.50 & $64,117.60$ \\
\hline Precipitation & 311 & $1,851.98$ & 487.85 & 995.90 & $3,099.80$ \\
\hline Temperature & 311 & 27.38 & 1.58 & 15.93 & 33.35 \\
\hline \multicolumn{6}{|c|}{ Northeast } \\
\hline $\bar{Y}$ & 1.048 & $12,139.47$ & $11,321.57$ & 556.00 & $12,6029.00$ \\
\hline Labor & 1.048 & $34,39.55$ & $2,822.72$ & 128.00 & $19,993.00$ \\
\hline Technology & 1.048 & 32.55 & 69.17 & 3.00 & $1,029.00$ \\
\hline Capital & 1.048 & $3,536.07$ & $4,236.54$ & 115.00 & $47,979.00$ \\
\hline Area & 1.048 & $19,197.62$ & $19,691.38$ & 239.00 & $174,093.00$ \\
\hline Irrigation & 1.048 & 139.78 & 254.23 & 1.00 & $2,946.00$ \\
\hline $\begin{array}{l}\text { Technical } \\
\text { assistance }\end{array}$ & 1.048 & 98.89 & 126.66 & 1.00 & $1,333.00$ \\
\hline Rural credit & 1.048 & $2,276.79$ & $2,475.39$ & 8.8 .00 & $41,908.48$ \\
\hline Precipitation & 1.048 & 853.76 & 412.97 & 159.40 & $2,201.60$ \\
\hline Temperature & 1.048 & 25.55 & 1.82 & 20.93 & 29.26 \\
\hline \multicolumn{6}{|c|}{ Southeast } \\
\hline$Y$ & 1.4239 & $17,509.67$ & $23,414.05$ & 301.00 & $246,647.00$ \\
\hline Labor & 1.4239 & $1,107.74$ & $1,332.36$ & 21.00 & $11,396.00$ \\
\hline Technology & 1.4239 & 142.44 & 211.52 & 3.00 & $2,854.00$ \\
\hline Capital & 1.4239 & $5,398.66$ & $8,663.33$ & 49.00 & $120,250.00$ \\
\hline Area & 1.4239 & $9,101.08$ & $11,261.51$ & 50.00 & $131,038.00$ \\
\hline Irrigation & 1.4239 & 79.97 & 219.38 & 1.00 & $3,654.00$ \\
\hline $\begin{array}{l}\text { Technical } \\
\text { assistance }\end{array}$ & 1.4239 & 114.01 & 147.74 & 1.00 & $1,527.00$ \\
\hline Rural credit & 1.4239 & $2,663.61$ & $3,689.31$ & 5.55 & $33,957.56$ \\
\hline Precipitation & 1.4239 & $1,133.63$ & 238.54 & 574.40 & $1,853.20$ \\
\hline Temperature & 1.4239 & 22.24 & 2.40 & 16.71 & 27.95 \\
\hline \multicolumn{6}{|c|}{ South } \\
\hline$Y$ & 1.149 & $37,895.43$ & $35,949.23$ & 459.00 & $305,540.00$ \\
\hline
\end{tabular}




\begin{tabular}{|c|c|c|c|c|c|}
\hline Labor & 1.149 & $1,393.86$ & $1,313.36$ & 54.00 & $17,462.00$ \\
\hline Technology & 1.149 & 481.51 & 514.94 & 3.00 & $5,791.00$ \\
\hline Capital & 1.149 & $13,416.11$ & $18,324.79$ & 1.00 & $397,199.00$ \\
\hline Area & 1.149 & $9,916.72$ & $9,301.36$ & 138.00 & $118,017.00$ \\
\hline Irrigation & 1.149 & 39.00 & 67.38 & 1.00 & 684.00 \\
\hline $\begin{array}{l}\text { Technical } \\
\text { assistance }\end{array}$ & 1.149 & 280.67 & 280.78 & 4.00 & $3,050.00$ \\
\hline Rural credit & 1.149 & $10,514.60$ & $11,766.32$ & 1.78 & $84,501.08$ \\
\hline Precipitation & 1.149 & $1,997.53$ & 379.24 & $1,153.50$ & $2,710.00$ \\
\hline Temperature & 1.149 & 20.19 & 1.91 & 15.21 & 24.50 \\
\hline \multicolumn{6}{|c|}{ Midwest } \\
\hline$Y$ & 430 & $21,344.22$ & $24,131.61$ & 821.00 & $274,775.00$ \\
\hline Labor & 430 & $1,235.75$ & $1,177.63$ & 30.00 & $8,454.00$ \\
\hline Technology & 430 & 123.34 & 145.17 & 4.00 & $1,132.00$ \\
\hline Capital & 430 & $6,862.46$ & 7,904.36 & 119.00 & $72,625.00$ \\
\hline Area & 430 & $22,550.33$ & $24,817.01$ & 694.00 & $175,627.00$ \\
\hline Irrigation & 430 & 23.07 & 35.89 & 1.00 & 253.00 \\
\hline $\begin{array}{l}\text { Technical } \\
\text { assistance }\end{array}$ & 430 & 78.56 & 93.52 & 1.00 & 685.00 \\
\hline Rural credit & 430 & $3,829.35$ & $5,393.01$ & 18.11 & $35,146.91$ \\
\hline Precipitation & 430 & $1,509.84$ & 297.81 & 880.60 & $2,780.70$ \\
\hline Temperature & 430 & 26.19 & 1.73 & 22.19 & 32.85 \\
\hline
\end{tabular}

Source: Elaborated by the authors according to IBGE (2017).

Table 7: SPF estimation using OLS.

\begin{tabular}{ccccccc}
\hline & Brazil North & Northeast & Southeast & South & Midwest \\
\hline Intercept & $0.3084 \quad 12385$ & $1.3525^{*}$ & -0.3908 & $2.6525^{*}$ & $4.4012^{*}$ \\
$\ln ($ Area $)$ & $0.0550^{*}$ & $0.1225^{*}$ & $0.0760^{*}$ & $-0.0450^{*}$ & -0.0182 & 0.0141 \\
$\ln ($ Technology) & $0.0905^{*}$ & 0.0471 & $0.0512^{*}$ & $0.0860^{*}$ & $0.1790^{*}$ & $0.1043^{*}$
\end{tabular}




\begin{tabular}{|c|c|c|c|c|c|}
\hline $\ln ($ Labor $)$ & $0.2109 * 0.3583 *$ & $0.1655^{*}$ & $0.3224 *$ & $0.2930 *$ & $0.1494 *$ \\
\hline $\ln ($ Capital) & $0.4978 * 0.3285^{*}$ & $0.4583^{*}$ & $0.5520 *$ & $0.4007 *$ & $0.5739 *$ \\
\hline $\begin{array}{l}\text { W[ln(Rural } \\
\text { credit) }\end{array}$ & $0.00700 .0391^{*}$ & 0.0307 & 0.0186 & $0.0303^{*}$ & $0.0847^{*}$ \\
\hline $\begin{array}{l}\ln (\text { Technical } \\
\text { assistance })\end{array}$ & $0.0598 * 0.0479$ & $0.0694 *$ & $0.0270 *$ & $0.1272 *$ & 0.0278 \\
\hline $\ln$ (Irrigation) & $0.0317 * 0.0682 *$ & $0.0585^{*}$ & 0.0047 & $-0.0362 *$ & $0.0351 *$ \\
\hline $\ln ($ Temperature $)$ & $-0.0452-0.3114$ & $-0.3588^{*}$ & -0.0193 & $0.4662 *$ & -0.1065 \\
\hline $\ln$ (Precipitation) & $0.3460 * 0.2711 *$ & $0.3727 *$ & $0.4140 *$ & $-0.1602 *$ & $-0.2367 *$ \\
\hline$R^{2}$ & $0.8940 \quad 0.8880$ & 0.7800 & 0.9010 & 0.9190 & 0.9030 \\
\hline Moran's I & $0.3062 * 0.2648 *$ & $0.3442 *$ & 0.2142 & $0.2306^{*}$ & $0.2205^{*}$ \\
\hline
\end{tabular}

Source: Elaborated by the authors according to IBGE (2017).

Note: * indicates statistical significance at $95 \%$ confidence level.

Table 8: Wald test results for null hypothesis $\theta=0$ and $\eta=0$.

\begin{tabular}{ccccccc}
\hline & Brazil & North & Northeast & Southeast & South & Midwest \\
\hline $\mathrm{k}=1$ & $123.2^{*}$ & 6.98 & $37.70^{*}$ & $37.03^{*}$ & $54.18^{*}$ & $20.84^{*}$ \\
$\mathrm{k}=2$ & $184.6^{*}$ & 7.47 & $57.30^{*}$ & $53.77^{*}$ & $72.85^{*}$ & $24.44^{*}$ \\
$\mathrm{k}=3$ & $191.2^{*}$ & 10.87 & $61.66^{*}$ & $53.94^{*}$ & $98.64^{*}$ & $24.54^{*}$ \\
$\mathrm{k}=4$ & $198.9^{*}$ & $22.64^{*}$ & $51.99^{*}$ & $62.08^{*}$ & $100.79^{*}$ & $26.73^{*}$ \\
$\mathrm{k}=5$ & $198.2^{*}$ & $24.55^{*}$ & $55.62^{*}$ & $61.87^{*}$ & $94.69^{*}$ & $34.42^{*}$ \\
$\mathrm{k}=10$ & $240.2^{*}$ & $36.79^{*}$ & $76.29^{*}$ & $75.81^{*}$ & $91.84^{*}$ & $42.30^{*}$ \\
\hline
\end{tabular}

Source: Elaborated by the authors according to IBGE (2017). 
Note: $*$ indicates statistical significance at $95 \%$ confidence level. 
Table 9: Brazilian family farming production in permanent crops.

\begin{tabular}{|c|c|c|c|c|c|}
\hline Product & North & Northeast & Southeast & South & Midwest \\
\hline Avocado (Tons) & 743 & 1436 & 42554 & 4779 & 552 \\
\hline A çá1 (fruit) (Tons) & 218216 & 1943 & 349 & 65 & 31 \\
\hline Acerola (Tons) & 3195 & 25597 & 3997 & 2374 & 133 \\
\hline $\begin{array}{c}\text { Agave, sisal (fiber) } \\
\text { (Tons) }\end{array}$ & - & 23477 & - & - & - \\
\hline $\begin{array}{c}\text { Agave, sisal (leaf) } \\
\text { (Tons) }\end{array}$ & - & 6745 & - & - & - \\
\hline Arboreal cotton (Tons) & - & 7 & - & - & - \\
\hline Plum (Tons) & - & - & 3808 & 19612 & - \\
\hline Blackberry (leaf) (Tons) & ) - & - & 6215 & 111319 & 527 \\
\hline $\begin{array}{c}\text { Blackberry (fruit) } \\
\text { (Tons) }\end{array}$ & - & - & 233 & 1538 & 0 \\
\hline Atemoya (Tons) & - & 86 & 924 & 88 & - \\
\hline Olive (olive) (Tons) & - & 0 & 99 & 98 & - \\
\hline Banana (Tons) & 201149 & 631640 & 501179 & 535146 & 84699 \\
\hline $\begin{array}{c}\text { Rubber (liquid latex) } \\
\text { (Tons) }\end{array}$ & 35 & 395 & 649 & 29 & 0 \\
\hline $\begin{array}{l}\text { Rubber (coagulated } \\
\text { latex) (Tons) }\end{array}$ & 84 & 4195 & 12495 & 21 & 853 \\
\hline Cocoa (almond) (Tons) & 47960 & 41449 & 990 & - & 82 \\
\hline $\begin{array}{l}\text { Arabica coffee beans } \\
\quad \text { (green) (Tons) }\end{array}$ & 968 & 9924 & 605449 & 38164 & 682 \\
\hline Canephora coffee & 32272 & 12080 & 187371 & 422 & 4644 \\
\hline
\end{tabular}


(tonnes)

\begin{tabular}{|c|c|c|c|c|c|}
\hline $\begin{array}{c}\text { Cashew (Chestnut) } \\
\text { (Tons) }\end{array}$ & 469 & 31623 & 2 & - & - \\
\hline Cashew (fruit) (Tons) & 611 & 28892 & 157 & - & 209 \\
\hline Camu-camu (Tons) & 6 & - & - & - & - \\
\hline Persimmon (Tons) & - & - & 10040 & 22683 & 1 \\
\hline Carambola (Tons) & 2 & - & 578 & 2 & - \\
\hline Indian Tea (Tons) & - & 0 & - & - & - \\
\hline $\begin{array}{l}\text { Coco-da-baya (A } \\
\text { thousand fruits) }\end{array}$ & 7359 & 211129 & 31477 & 385 & 1413 \\
\hline Clove (Tons) & - & 1197 & - & - & - \\
\hline $\begin{array}{l}\text { Oil palm (coconut) } \\
\text { (Tons) }\end{array}$ & 33113 & 8142 & 34 & - & 10 \\
\hline Yerba Mate (Tons) & - & - & - & 171820 & 145 \\
\hline Fig (Tons) & - & - & 1095 & 2246 & 0 \\
\hline Conde fruit (Tons) & 6 & 4766 & 110 & - & - \\
\hline Guava (Tons) & 1402 & 32272 & 28508 & 4077 & 1553 \\
\hline $\begin{array}{c}\text { Soursop (A thousand } \\
\text { fruits) }\end{array}$ & 370 & 4124 & 100 & - & 16 \\
\hline Guarana (Tons) & 328 & 735 & - & - & 44 \\
\hline Jabuticaba (Tons) & 29 & 213 & 353 & 197 & 169 \\
\hline $\begin{array}{c}\text { Jackfruit (Thousand } \\
\text { fruits) }\end{array}$ & 92 & 1223 & 132 & - & - \\
\hline Jambo (Tons) & - & 51 & 2 & - & - \\
\hline
\end{tabular}




\begin{tabular}{|c|c|c|c|c|c|}
\hline kiwi (tons) & - & - & 37 & 2515 & - \\
\hline Orange (Tons) & 37035 & 228011 & 601796 & 216195 & 9621 \\
\hline Lychee (Tons) & - & - & 1424 & 385 & 1 \\
\hline Lima (Tons) & - & 287 & 2103 & - & - \\
\hline Lemon (Tons) & 18212 & 19170 & 173186 & 10005 & 2380 \\
\hline Laurel (leaf) (Tons) & - & - & 731 & - & - \\
\hline apple (tons) & - & - & 312 & 196151 & - \\
\hline Sleeve (Tons) & 540 & 105464 & 60562 & 653 & 388 \\
\hline Papaya (Tons) & 13857 & 43874 & 21991 & 71 & 3248 \\
\hline Passion fruit (Tons) & 13067 & 105764 & 34130 & 33731 & 5107 \\
\hline Nectarine (Tons) & - & - & 66 & 1889 & - \\
\hline Loquat (Tons) & - & - & 347 & 15 & - \\
\hline $\begin{array}{l}\text { Walnut (European, } \\
\text { Pecan) (Tons) }\end{array}$ & - & - & 0 & 514 & - \\
\hline Heart of palm (Tons) & 165 & 1700 & 9562 & 20716 & 2598 \\
\hline Pear (Tons) & - & - & 136 & 3806 & - \\
\hline Peach (Tons) & - & - & 3892 & 89545 & - \\
\hline Black pepper (Tons) & 16374 & 1296 & 12887 & - & 20 \\
\hline Pitaia (Tons) & 33 & 1 & 536 & 375 & 5 \\
\hline Pitanga (Tons) & - & 18 & 6 & 8 & - \\
\hline Pomegranate (Tons) & - & 87 & 44 & 3 & - \\
\hline Tangerine, Bergamot, & 3346 & 9722 & 89610 & 101585 & 8131 \\
\hline
\end{tabular}


Tangerine (Tons)

$\begin{array}{lccccc}\text { Urucum (seed) (Tons) } & 2081 & 919 & 2359 & 376 & 339 \\ \begin{array}{c}\text { Grape (table) (Tons) } \\ \text { Grape (wine or juice) } \\ \quad\end{array} & 8 & 21474 & 36831 & 44927 & 101 \\ \quad \text { (Tons) } & 2 & 35 & 1246 & 657910 & 288 \\ \begin{array}{c}\text { Pupunha (fruit bunch) } \\ \quad \text { (Tons) }\end{array} & 4478 & 372 & 91 & 101 & 183 \\ \quad \begin{array}{c}\text { Cupuacu (Tons) } \\ \quad 11750\end{array} & 2197 & 14 & - & 141 \\ \text { Other products (Tons) } & 1695 & 22887 & 2574 & 4171 & 412\end{array}$

Source: Elaborated by the authors according to IBGE (2017).

Note: The symbol "_" represents data without information.

Table 10: Brazilian family farming production in temporary crops.

\begin{tabular}{cccccc}
\hline Product & North & Northeast & Southeast & South & Midwest \\
\hline $\begin{array}{c}\text { Pineapple } \\
\text { (Thousand fruits) }\end{array}$ & 142228 & 134078 & 172189 & 6089 & 22538 \\
$\begin{array}{c}\text { Pumpkin (Tons) } \\
\text { Herbaceous }\end{array}$ & 20386 & 73332 & 57181 & 75637 & 14539 \\
$\begin{array}{c}\text { cotton (Tons) } \\
\text { Garlic (Tons) }\end{array}$ & 18 & 1656 & 427 & - & 1050 \\
$\begin{array}{c}\text { Peanuts in Shell } \\
\text { (Tons) }\end{array}$ & 816 & 1292 & 4416 & 14963 & 104 \\
$\begin{array}{c}\text { Rice in husk } \\
\text { (Tons) }\end{array}$ & 56243 & 157372 & 8500 & 951093 & 34327 \\
$\begin{array}{c}\text { White oat grain } \\
\text { (Tons) }\end{array}$ & - & & 16042 & 2422 & 507 \\
\end{tabular}


English Potatoes

(Tons)

Sugarcane

(Tons)

Onion (Tons)

Rye in grain

(Tons)

Barley in husk

(Tons)

Rape (Tons)

Pea beans (Tons)

Broad Bean

(Tons)

449

406

Black beans in
beans (Tons)

Colored beans in

beans (Tons)

Black beans in

beans (Tons)

Green beans

(Tons)

Smoke in dry

leaf (Tons)

Sesame (seed)

(Tons)

12

Sunflower (seed)

(Tons)

191
$1303 \quad 706$

149614

92641

584

39944

2027205

8634295

913502

691463

69115

28090

370061

126

3

1

340

36420

3642

4

283

116

9

17016

239

33

9

$4738 \quad 50699$

54715

34308

5931

8053134016

5911

359

9211

$2727 \quad 33444$

2201

407

420

7241

457

563320

67

145

24

0

210

13

575

188

419 


\section{Jute (fiber)}

(Tons)

Linen (fiber)

(Tons)

Malva (fiber)

(Tons)

Castor bean

(Tons)

Cassava (Tons)
Watermelon
(Tons)
Melon (Tons)
Corn in grain
(Tons)
Ramie (fiber)

(Tons)

Soybeans (Tons)

111286

3335

4

9029

1644422

1089469

478391

$1045387 \quad 305153$

168037

29037

701628

35

Sorghum grain (Tons)

Broom Sorghum (Tons)

3

1450

5436

160

805

1264

19

Creeping Tomato

(Tons)

931

70670

21195

$6660 \quad 10907$

Wheat in grain

(Tons)

Black Wheat

Grain (Tons)
5

32

$93570 \quad 29670$

$5780 \quad 466$

1420917 
Triticale in grain (Tons)

Forages for

cutting (Tons)

$1838 \quad 214864$

351139

252762

7420

Forage cane

(Tons)

$6321 \quad 53958$

1304357

142224

97389

Forage corn

(Tons)

18915

1047827

5037156

15036338

1025345

Forage palm

(Tons)

2049652

6345

687

379

Forage sorghum

(Tons)

$3402 \quad 219371$

268582

124340

32960

Other products

(Tons)

$4117 \quad 18037$

42964

$63971 \quad 7489$

\section{Cotton Seeds}

(Tons)

Rice Seeds (Tons)

Bean Seeds<smiles>[TeH][TeH2]</smiles>

428

13

67

3

Corn Seeds (Tons)

41

259

1129

670

2956

Soy Seeds (Tons)

2178

77

3639

3757

1178

Wheat Seeds

(Tons)

Forage Seeds

(Tons)

240

4284

4413

2261

Potato Seeds

0

296

888 
(Tons)

Sugarcane billets

(Tons)

Other products

(Tons)
7

75
22

1467

103

33

250

1607

695

1269

Source: Elaborated by the authors according to IBGE (2017).

Note: The symbol “-” represents data without information.

Table 11: Estimated population by region of Brazil.

\begin{tabular}{cc}
\hline Region & Total population in 2017 \\
North & $17,936,201$ \\
Northeast & $57,254,159$ \\
Southeast & $86,949,714$ \\
South & $26,644,948$ \\
Midwest & $15,875,907$ \\
\hline
\end{tabular}

Source: Elaborated by the authors according to IBGE (2021).

\section{Copyright Disclaimer}

Copyright for this article is retained by the author(s), with first publication rights granted to the journal.

This is an open-access article distributed under the terms and conditions of the Creative Commons Attribution license (http://creativecommons.org/licenses/by/4.0/). 